\title{
The Cross-Section Requirement and Jury Impartiality
}

In the tangled history of challenges to state criminal-jury selection procedures, a number of different standards have emerged. In 1968, the Supreme Court sought to impose a uniform sixth amendment standard on the states. ${ }^{1}$ The Court has since struggled to define this standard and to resolve earlier contradictory pronouncements regarding due process and equal protection challenges.

This Comment argues that the Court has not realized its ambitions. Part I begins by assessing the potential tension between the sixth amendinent notion of impartiality and the ordinary-language sense of impartiality. Section $A$ concludes by suggesting that the nature of voir dire and the difficulty in attaining a petit jury truly representative of the community place the sixtlı amendment ideal out of reach. Section $B$ summarizes the standards for reviewing exclusions at each stage of selection. This Section will demonstrate that the state's burden of rebuttal under the various standards is consistently low.

The discussion then noves to the various standards for reviewing voir dire challenges. The touchstone for analysis is the Second Circuit's recent effort to articulate a distinct sixth amendment standard. This fornulation is then compared witl the convoluted fourteenth amendment standard elaborated in Swain v. Alabama. ${ }^{2}$ Section $B$ concludes witl a brief description of the various ways in which state supreme courts, relying on their own constitutions, lave managed to sidestep Swain.

Part II evaluates the current state of the law and proposes several major changes. Section $A$ speculates that courts remain uncertain over the strengtli of a defendant's interest in trial by impartial jury and that the resulting lax enforcement compromises fundamental due process interests. Sections $B$ and $C$ discuss two California cases whiclı illustrate how even this most activist of jurisdictions seems reluctant to apply the cross-section requirement in the early stages of selection, althougli it does not hesitate to extend it inappropriately into tlie stage of voir dire.

Section $D$ argues that the selection process im its earlier stages should be reviewed under an equal protection standard, since the prospective juror's interest in not being arbitrarily stricken is strongly implicated, whereas the challenger's sixth amendment interest in impartial judginent is only remotely at issue. This Section also concludes that

1. Duncan v. Louisiana, 391 U.S. 145 (1968).

2. 380 U.S. 202 (1965). 
courts should review voir dire under a modified sixth amendment standard to minimize the significance of cross-sectionality.

Section $E$ suggests adjusting the standards to reflect more accurately the constitutional issues at various stages of selection. The Section begins by suggesting that to attempt a balancing of demonstrably prejudiced perspectives in the stage of voir dire is constitutionally impermissible. The discussion goes on to describe how peremptory challenges compromise a series of constitutional interests by precluding meaningful review. As a means for dealing with this problem, the Section proposes abandoning peremptory challenges altogether and broadening the grounds for challenges based on cause. The effect of such a change would be not only to place discretion to exclude in the hands of the court, but also to develop a more meanimgful record for appellate review.

I

The Current State of the Law

\section{A. The Fundamental Nature of the Right to Criminal Trial by an Impartial Jury}

In recent years, the American courts have both declared the fundamental nature of the right to trial by an impartial jury and defined that right in terms of a jury's reflection of general demographic patterns. In Duncan v. Louisiana, the Supreme Court characterized a criminal defendant's interest im trial by jury as "fundamental to the American scheme of justice." 3 The Court accordingly held that the sixth amendment must apply to the states through the fourteenth. Seven years later, Taylor v. Louisiana ${ }^{4}$ extended the holding of Duncan by declaring that a defendant has a fundamental interest in trial before a jury selected from a fair cross section of the community. ${ }^{5}$

This holding is fully consistent with decisions founded on other constitutional authority ${ }^{6}$ and with federal statutory law. ${ }^{7}$ There has been

3. Duncan v. Louisiana, 391 U.S. 145, 149 (1968).

4. 419 U.S. 522 (1975).

5. Id. at 530. The Court remarked that "the presence of a fair cross-section of the community on venires, panels, or lists from which petit juries are drawn is essential to the fulfillment of the Sixth Amendment's guarantee of an impartial jury trial in criminal prosecutions." Id. at 526; see id. at 528. Williams v. Florida, 399 U.S. 78, 100 (1970), anticipated this pronouncement by suggesting in passing that Duncan implied a representative cross-section requirement.

6. For example, in Smitlı v. Texas, 311 U.S. 128, 130 (1940) the Court held that a state policy systematically excluding blacks from jury service violates the equal protection clause of the fourteenth amendment, since the resulting jury cannot be "a body truly representative of the community." In Glasser v. Umited States, 315 U.S. 60, 85-86 (1942), the Court relied on the Smith phrasing in the sixtl amendment context to support a conclusion that a jury must not be "the organ of any special group or class." In Ballard v. Umited States, 329 U.S. 187, 193, 195-96 (1946), the Court exercised its supervisory power over the federal courts to reverse a conviction by an all-male jury, simce systematic exclusion of women violates the cross-section requirement. 
considerable controversy about the scope of a challenger's interest in cross-sectionality. ${ }^{8}$ Nevertlieless, Taylor lias placed the application of the cross-section principle in jury selection beyond dispute.

Before considering whetler cross-sectionality can indeed insure impartiality, it is useful to note the official reasons wliy jury trial lias been characterized as a fundamental riglit. In Duncan, Justice White explained:

A right to jury trial is granted to criminal defendants in order to prevent oppression by the Government. . . . Providing an accused with the right to be tried by a jury of his peers gave him an inestimable safeguard against the corrupt or overzealous prosecutor and against the compliant, biased, or eccentric judge. If the defendant preferred the coinmon-sense judgment of a jury to the inore tutored but perhaps less sympathetic reaction of the single judge, he was to have it. . . . Fear of unchecked power ... found expression in the criminal law in this insistence upon community participation in the determination of guilt or innocence. 9

Various priorities einerge from this formulation: the Court seemed to sanction sucl traditional goals as interposing a body of citizens between the accused and the state, promoting citizen participation for its own sake, imbuing the judicial system witl the "common sense" of public judgment and tempering justice with mercy as the popular will dictates.

Justice White's catalogue of priorities suggests that the defendant's interest in avoiding oppression is not the sole reason for trial by jury. There is also a juror's interest in serving, which the defendant is given standing to enforce. Peters $v$. Kiff ${ }^{10}$ expanded the concept of standing by allowing the defendant to bring a fourteenth amendinent cliallenge to selection-procedure violations committed against anyone involved in the trial. Duncan established that the same interests apply in a sixtli amendinent context. Since Taylor, whenever the issue of standing lias arisen in a sixtl amendment context, it lias been couched in ternns of crosssectionality.

Under both sixth and fourteentlı amendment analysis, tlien, the coincidence of defendant's and juror's interests is seen to assure imparti-

7. Federal Jury Selection \& Service Act, 28 U.S.C. $\$ 1861$ (1982) (litigants "have the right to grand and petit juries selected at random from a fair cross section of the community").

8. This controversy is most troublesome at the petit jury level with respect to peremptory challenges. See infra notes 67-127 and accompanying text.

9. 391 U.S. at $155-56$.

10. 407 U.S. 493 (1972). In Peters, the Court held that a defendant has standing to protest the exclusion of any cognizable group regardless of whether such exclusion has compromised his interest in a fair trial. Id. at 498. Notwithstanding the fact that an "arbitrary and discriminatory" mechanism may work solely against the unrelated interests of third parties, a defendant may sue on such interests for reasons of public policy. Id. at 502 . This right is supported by, but not contingent upon, the possibility that a systematic exclusion may produce a subtle, undemonstrable prejudice. The presumption of other types of harm will suffice. Id. at 498 . 
ality. The concept of impartiahity consequently has come to designate both the detachment of the selection process and the detachment of the individual jurors. ${ }^{11}$ The retreat from cross-sectionality in the final stage of selection implies an ordering of the interests enumerated in Duncan. In voir dire, the juror's interest in serving is less fundamental than the defendant's interest in disinterested judgment. The former interest is subordinate whenever counsel either establishes juror partiality or suspects partiality and exercises a peremptory challenge. Thus, the ideal of citizen participation in justice yields to the more fundamental ideal of

11. The Court declared nearly fifty years ago in United States v. Wood, 299 U.S. 123, 145-46 (1936), that a defendant can expect a "niental attitude of appropriate indifference" in the body that judges him. Ten years later, in Thiel v. Southern Pac. Co., 328 U.S. 217, 227 (1946) (Frankfurter, J., dissenting), Justice Frankfurter apparently recognized the distinction between systeinic and individual impartiality when he noted that "[t]rial by jury presupposes a jury drawn from a pool broadly representative of the community as well as impartial in a specific case." Unfortunately, he went on to confuse the issue by suggesting that "the broad representative character" of a jury will serve to assure its "diffused impartiality." Id.

This formulation seenus to reflect a suspicion that individual inpartiality is either impossible to attain or beyond reliable denionstration. As a result, one can do little nore than the Court did in Peters: proscribe the systeniatic exclusion of any "perspective on human events that may have unsuspected importance" in a jury's decision. 407 U.S. at 503-04. In Taylor, this conception of impartiality as a procedural, rather than a psychological, condition culminated with the Court's definition of "biased juries" nierely as ones that "reflect a slanted view of the community they are supposed to represent." 419 U.S. at 529 n.7 (quoting H.R. REP. No. 1076, 90th Cong., 2d Sess. 8 (1968)). Impartiality, under the Taylor view, is unore an attribute of juries than jurors-literally unattainable in an unrepresentative body.

Despite this trend towards equating impartiality and cross-sectionality, the notion of impartiality as an individual niental state survives in the final stage of jury selection. At this point, opposing counsel may question prospective jurors and then challenge them either pereinptorily or for cause. This process of voir dire niay well make the jury less representative than would be the case if the selection were conducted solely at random. Only a conception of impartiality different from that propounded in Taylor can justify this result. While he enibraces a notion of impartiality as representativeness, Jon Van Dyke aptly summarizes the inconipatibility of this notion with the rationale underlying challenges.

The purpose of challenges is to eliminate jurors who niay be biased about the defendant, the prosecution, or the case, and who thus night threaten the jury's impartiality. Challenges can theoretically serve to even out the disproportions when the process of selecting jurors has distorted the deniographic profile of the cominunity, as is often the case. They may, however, nrake the jury still less representative, even to the point of renoving all nuembers of a certain race or social group fron the jury. And if the jury panel sent into the courtroom is representative and thus fairly reflects the comnunity's biases, challenging certain jurors because of their prejudices may alter the cross-section of views represented.

J. Van Dyke, Jury Selection Procedures: OUR Uncertaln Commitment to RepresentaTIVE PANELS 139 (1977) (footnote ornitted).

The Court's pronouncenients in defense of pereniptory challenges have done little to reconcile these two notions. In Swain, Justice White stated that pereniptory challenges "elimimate extrenies of partiality on both sides" and so assure that jurors "will decide on the basis of the evidence placed before them, and not otherwise." Swain v. Alabaina, 380 U.S. 202, 219 (1965). Thus, ironically, the Court invoked the concept of imdividual impartiality to support this conpronise of systemic impartiality, furtlier confusing the two. Whatever the merits of the specific loolding in Swain, the case suggests that the cross-section principle can be abandoned in the interests of juror inpartiality. 
juror indifference, and the goal of systemic impartiality gives way to the notion of individual impartiality.

This ordering, however, appears to conflict with the language of cases such as Taylor, which increasingly tend to define impartiality in terins of cross-sectionality. ${ }^{12}$ Sections $D$ and $E$ will suggest that Justice White's call for "community participation" in Duncan can be reconciled with his opimion in Swain restricting community participation only by distinguishing the constitutional interests at the various stages of juror selection. The Court itself, however, has yet to develop a distinctly sixth ainendinent standard of review for impartiality in voir dire. For the inoment, we are confronted with a standard that both celebrates crosssectionality and countenances dehiberate exclusions-extremes of imterpretation einbraced in the conviction that both serve an interest whose fundainental nature is itself elusive. ${ }^{13}$

\section{B. Federal and State Enforcement Standards}

\section{The Standard for Challenging Petit Jury Selection}

The federal method of jury selection provides a general model of the systeins adopted in the inajority of jurisdictions. The Federal Jury Selection and Service Act provides that a inaster wheel of jurors inust be compiled by random selection from sources representative of the community. ${ }^{14}$ Section 1864 calls for the random selection froin this

12. By the time of Duren v. Missouri, 439 U.S. 357, 359-60 (1979), the Court had so accepted the equation of impartiality and cross-sectionality that it simply substituted the latter concept for the former in summarizing the sixth and fourteenth amendment standards. The California Supreme Court in Wheeler justified its own analysis by remarking that for almost forty years "the United States Supreme Court has held that an essential prerequisite to an impartial jury is that it be drawn from 'a representative cross-section of the community." " $22 \mathrm{Cal}$. 3d at 266, 583 P.2d at 754, 148 Cal. Rptr. at 896 (footnote omitted).

13. See infra notes $140-55$ and accompanying text. The Court has recently granted certiorari in a case that involves a sixth amendment cross-sectional challenge to the exclusion of blacks from a jury by the prosecutorial use of peremptories. Batson v. Kentucky, cert. granted, $105 \mathrm{~S}$. Ct. 2111 (April 22, 1985). In an unpublished decision, the Kentucky Supreme Court held in Batson that a black defendant's sixth amendment rights were not violated when a prosecutor used four of his six peremptories to strike all black veniremembers from a panel. See 53 U.S.L.W. 3784, April 30, 1985; Lauter, Race Dominates Court's Docket, Nat'1 L.J., October 7, 1985, at 1, col. 2, at 25, col. 3. In addressing this question, the Supreme Court may resolve the relationship between the concepts of systemic impartiality (i.e., cross-sectionality) and individual juror impartiality (supposedly assured by the process of voir dire). The Court may extend the principle of cross-sectionality into the stage of voir dire, thus reaffirming the notion of impartiality espoused in Taylor. The California Supreme Court has already taken this step on the strength of the state constitution in People v. Wheeler, 22 Cal. 3d 258, 583 P.2d 748, 148 Cal. Rptr. 890 (1978). For a discussion of this case and its implication, see infra notes $117-40,171-79$ and accompanying text. The Court alternatively may affirm Swain, thereby indicating that impartiality cannot be consistently equated with crosssectionality in a sixth amendment context. Finally, it may attempt to reconcile the potential conflict in the stage of voir dire between the notions of impartiality as a condition of cross-sectionality and as a demonstrable mental state.

14. 28 U.S.C. $§ 1863$ (1982). 
wheel of as many people as may be required for service on grand and petit juries. A questionnaire mailed to these potential jurors enables jury commissioners to compile a narrower hist of qualified jurors, who will be called for service by random selection as the need arises. ${ }^{15}$ The venire comprises the group of people thus selected, and individual members are subject to voir dire examination and possible exclusion. ${ }^{16}$ Veniremembers may be excused on a showing of undue hardship or extreme inconvenience. ${ }^{17}$ There are thus three distinct stages in federal jury selection: the random compilation and narrowing of the jury wheel; the granting of excuses; and the process of challenging veniremembers in voir dire. ${ }^{18}$ While the cross-section principle supplies the standard for nnpartiality in the first stage, its applicability ni voir dire is debatable. A review of current standards thus requires that the allocation of burdens be considered separately for each stage.

\section{a. Excuses and Hardship Exemptions}

The scope of exenıtions from service for hardship and inconvenience necessarily resists reduction to formula. However, the clear tendency simce Taylor has been to grant such exemptions only grudgingly. In both Taylor and Duren v. Missouri, ${ }^{19}$ the Court defined a narrow area within which a court nnight exercise discretion. It held that both juror qualification standards and the granting of hardship exemptions invite judicial scrutiny ouly to the extent that they represent "threats that the remaining pool of jurors would not be representative of the community." 20 They will be approved if a "significant state interest [is] manifestly and primarily advanced." ${ }^{.11}$ Unaccountably, this standard is less stringent than that usually imposed when a fundaniental right is compromised. ${ }^{22}$ The closing Sections of this Comment will discuss some possible causes of this anomaly.

\section{b. Venire Composition: The Elements of a Prima Facie Violation}

No state has yet rehied on its constitution to innpose a stricter burden in jury wheel and venire selection than is compelled by the sixth aniendment. Since Duncan incorporated the sixth into the fourteenth aniendment, defendants challenging state court procedures in this stage of

15. Id. at $\$ 1864$.

16. Id. at $\S 1866$.

17. Id.

18. For an extensive discussion of each of these stages in both federal and state proceedings, see VAN DYKe, JURY SELECTION supra note 11, at 85-175.

19. 439 U.S. 357 (1979).

20. Taylor, 419 U.S. at 534.

21. Duren, 439 U.S. at 367.

22. See infra notes 87-145 and accompanying text, discussing the state's burden of rebuttal. 
selection must invoke a standard virtually identical to the federal standard. Therefore, this discussion will focus on state law only when the enforcement or interpretation of the essentially uniform standard seems distinctive. This is occasionally true of California, which aggressively pursues the cross-sectional ideal.

The elements of a prima facie violation in the early stages of selection were detailed in Duren, which reaffirmed Taylor's stress on crosssectionality. The Court bluntly declared that "disproportion itself demonstrates an nifringement of the defendant's interest in a jury chosen from a fair community cross section."23 Duren specifically requires a challenger to establish three things: first, that the excluded group is "distinctive"; second, that representation of this group on venires is unfair and unreasonable relative to its representation in the commumity; and third, that the discrepancy is the result of systematic exclusion in the jury-selection process. ${ }^{24}$

i. The cognizability requirement. The federal courts have proposed various formulations for determining whether a group should be considered cognizable. ${ }^{25}$ The Supreme Court originally defined cognizability in ternis of whether a group had been singled out for distinctive treatment in the past. ${ }^{26}$ In Peters v. Kiff,, ${ }^{27}$ the Court offered a fornulation that was less colored by the orientation of equal protection. It suggested that a group is legally cognizable to the extent that it displays distinctive "qualities of human nature and varieties of human experience" or a umique perspective on events. ${ }^{28}$ Similarly, in Taylor the Court focused not on sex discrimination but on the fact that "the two sexes are not fungible."29

23. 439 U.S. at 368 n.26.

24. Id. at 364 .

25. The term "cognizable" has been used in a number of cases. See, e.g., United States v. Greene, 489 F.2d 1145, 1149 (D.C. Cir. 1973); United States v. Test, 399 F. Supp. 683,688 (D. Colo. 1975); United States v. Guzman, 337 F. Supp. 140, 143 (S.D.N.Y.), affd, 468 F.2d 1245 (2d Cir. 1972); People v. Wheeler, 22 Cal. 3d 258, 280, 583 P.2d 748, 764, 148 Cal. Rptr. 890, 904-05 (1978). For a defense of this label as "most appropriate . . . for Sixth Amendment purposes," see Note, Limiting the Peremptory Challenge: Representation of Groups on Petit Juries, 86 YALE L.J. 1715, 1735 n.83 (1977).

26. Hoyt v. Florida, 368 U.S. 57, 60 (1961) (citmg Hernandez v. Texas, 347 U.S. 475,478 (1954)). Hoyt was a fourteenth amendment challenge predating Duncan's application of the Sixth Amendment to the states. The Hoyt definition of cognizability was refined in Castaneda v. Partida, 430 U.S. 482, 494 (1977), where the Court forbade the exclusion from grand jury service of any "recognizable, distinct class, singled out for different treatment under the laws as written or applied." Castaneda muolved a challenge to the conposition of a grand jury. Since the fifth amendnient's gnarantee of a right to a grand jury proceeding in criminal cases has not been extended through the fourteenth amendnient to apply to the states, the challenger's claim, as in Hoyt, rested solely on the fourteenth amendinent's assurance of due process and equal protection. See infra note 155 and aeconipanying text.

27. 407 U.S. 493 (1972).

28. Id. at 503-04.

29. 419 U.S. at 531-32 (quoting Ballard, 329 U.S. at 193-94). 
Distinctiveness, then, rather than the prejudice it engenders, has becoine the primary focus of sixth amendinent review for cognizability. Historical discrimination reinams a factor, however, and in all probability groups clearly identifiable as "discrete and insular minorities" be inost readily recognized at law. The courts have inconsistently applied the various definitions under both sixth and fourteenth annendinent analyses to uphold group claims based on race, ${ }^{31} \mathrm{sex}^{32}$ national origin, ${ }^{33}$ religion, ${ }^{34}$ and economic status. ${ }^{35}$

California's standard for determining cognizability elaborates the approach adopted in Peters and Taylor. In Rubio v. Superior Court, ${ }^{36}$ the supreine court outlined a standard that miposes on the defendant the burden of establishing two things. First, he inust prove that ineinbers of the group share a "common perspective" which was "gained precisely because they are members of that group." In addition, he must show that only members of the group can adequately represent this perspective. ${ }^{37}$ Thus, under the two-pronged Rubio test, review focuses on the representation of distinctive attitudes, rather than the proportional representation of the group holding these attitudes.

The court in People v. Harris ${ }^{38}$ tentatively questioned on cross-sectional grounds the constitutional validity of this second prong. It reasoned that to exclude a group because its attitudes resenble those of another group is to distort the proportion of people sharing that attitude in the general population. ${ }^{39}$ However, this criticism appears only in a footnote, and the body of the opmion presents the dual-prong standard intact.

Yet anotlier standard for determining coginzability imvolves an act of judicial deference to a clear constitutional expression of public will. In Commonwealth v. Soares, ${ }^{40}$ the Massacliusetts Supreine Court linited the imperimissible classifications to those specified in the state's Equal Rights Amendinent: sex, race, color, creed, and national origin. The availabil-

30. The phrase was coined by Justice Stone in his famous footnote to United States v. Carolene Products, 304 U.S. 144, 152 n.4 (1938), and describes those groups whose fourteenth amendnent rights are now held to warrant especially stringent protection by reviewing courts.

31. See, eg., Peters, 407 U.S. at 493.

32. See, eg., Taylor, 419 U.S. at 522.

33. See, e.g., State v. Plenty Horse, 85 S.D. 401, 184 N.W.2d 654 (1971).

34. See, e.g., Juarez v. State, 102 Tex. Crim. 297, 277 S.W. 1091 (1925).

35. See, e.g., Thiel v. Southern Pac. Co., 328 U.S. 217, 223 (1946).

36. 24 Cal. 3d 93, 593 P.2d 595, 154 Cal. Rptr. 734 (1979).

37. Id. at 98, 593 P.2d at 598, 154 Cal. Rptr. at 737. Justice Tobriner strongly protested the second prong as "fashioned by the majority out of whole cloth," although he aeknowledged that several federal district court decisions had imposed a similar restriction. Id. at 105 \& n.1, 593 P.2d at 603 \& n.1, 154 Cal. Rptr. at 742 \& n.1 (Tobriner, J., dissenting).

38. 36 Cal. 3d 36, 679 P.2d 433, 201 Cal. Rptr. 782, cert. denied, 105 S. Ct. 365 (1984).

39. Id. at 51 n.5, 679 P.2d at 441 n.5, 201 Cal. Rptr. at 790 n.5.

40. 377 Mass. 461,387 N.E.2d 499, cert. denied, 444 U.S. 881 (1979). 
ity of this approach depends upon a court's access to such an amendment and requires that the enumerated categories be at least coextensive with those mandated by federal constitutional guarantees.

The factual issue in reviewing the use of juror sources is whether the hists adequately represent a group whose existence is constitutionally cognizable. The court must resolve this question in the challenger's favor before it will even consider cross-sectionality. For example, the category of people failing to register to vote is not cognizable. ${ }^{41}$ Thus, courts have permitted the exclusive use of voter registration hists as a juror source except where cognizable groups are poorly reflected or statutory restrictions preclude a group's presence on the voting rolls. ${ }^{42}$

41. See, e.g., United States v. Tillman, 272 F. Supp. 908 (N.D. Ga. 1967),vacated in part, 395 U.S. 830 (1969) (per curiam); People v. Sirhan, 7 Cal. 3d 710, 749-50, 497 P.2d 1121, 1148, 102 Cal. Rptr. 385, 412 (1972), cert. denied 410 U.S. 947 (1973). Both courts and commentators have at tines failed to grasp that the noncognizability of those who fail to register does not automatically legitimize voter registration lists as a single source. In his highly influential study of jury composition cases, for instance, Judge Gewin cited a number of cases that rejected such conparative data on the reasoning that "personal predilection not to register cannot serve as a basis for menibership in a cognizable group." Gewin, An Analysis of Jury Selection Decisions, attached as an appendix to Foster v. Sparks, 506 F.2d 805, 811 (5th Cir. 1975) [hereinafter cited as Gewin, Jury Selection]. This criticism suggests either a confusion of the noncognizable category of unregistered voters with what might be a largely coextensive category defined by some cognizable characteristic, or else an imwarranted conclusion that a cognizable group nember's failure to vote betrays such civic incompetence that the member should lose his right to be considered for jury service. Justice Mosk opeuly expressed the latter view in his Harris dissent. $36 \mathrm{Cal}$. 3d 36, 74, 679 P.2d 433, 457, 201 Cal. Rptr. 782, 806, cert. denied, 105 S. Ct. 365 (1984). Duren, however, exphcitly rejected the proposition that comphance with the fair cross-section requirenent might be denuonstrated simply by coinparing the composition of veuires with that of voter registration lists. 439 U.S. 357,365 n.23 (1979).

42. Voter ehigibility requirements tend roughly to mateh those for jury service. The California Constitution stipulates that a voter must be a resident citizen, over 18 , nientally competent, and neither miprisoned nor on parole for a felony conviction. CAL. CoNST. art. II $\S \S 2,4$. The California Code of Civil Procedure contains virtually identical requirements for jurors, providing in addition that a prospective juror must speak English. CAL. Crv. Proc. CodE $\S 198$ (West 1982). The Code further disqualifies all convicted felons, rather than merely those serving time or on parole. Id. § 199. Jnstice Tobriner vigorously attacked this restriction in his Rubio disseut. 24 Cal. 3d at 105-17, 593 P.2d at 603-11, 154 Cal. Rptr. at 742-50. A general correspondence between eligibility requirenents for voting and jury service nuay be compelled by federal constitutional inperatives. To the extent that the two sets of standards diverge, however, whether permissibly or not, a real possibility remains that the sole use of voter lists in einpanehug juries will lead to the exclusion of cognizable groups.

The Jury Selection and Service Act, 28 U.S.C. $\$ \S 1861-1874$ (1982), established a general duty to supplement source lists when a single source proves inadequate. Congress further explicitly inandated such supplementation when voter registration lists deviate substantially fron the community's overall demographic patterns. S. REP. No. 891, 90th Cong., Ist Sess. 17 (1967). In theory, then, failure to supplenent such lists constitutes a systenatic exclusion of the sort discussed infra notes 55-57 and accompanying text, but few if any federal cases have quashed a jury on this ground. California requires the supplemental use of DMV lists when such inclusion can be effected practically and "without significant cost." CAL. Civ. Proc. CODE § 204.7 (West Supp. 1985). Despite sueh directives, no case before Harris has invalidated a state's indisputably random seleetion of jurors from a voter registration list. 
ii. The unfair representation requirement. The second requirement under Duren for estabhishing a prima facie violation is a showing that a cognizable group has been unfairly represented on venires in relation to its nuinbers in the commumity. There is no right to have a particular group represented on a given grand jury, venire, or petit jury. ${ }^{43}$ Protection rather is limited to an assurance that no group will be systematically excluded, ${ }^{44}$ and a purely fortuitous deviation froin the ideal inakeup of a jury does not in itself constitute a violation. ${ }^{45}$ Some courts tend to minimize the significance of even considerable disparities over time, reasoning that these might result froin the legitimate qualification requirements and exemptions based on hardship and mcapacity. ${ }^{46}$

It is apparent that a comparison between a group's representation on a venire and its representation among eligible jurors would be the inost meaningful. However, data on the population of ehgible jurors are often unavailable, ${ }^{47}$ and courts therefore generally accept overall population data as a substitute. By suggesting that community ratios, rather than representation in voter registration hists, should serve as a basis for coinparison, ${ }^{48}$ Duren lent support to the use of data from the total population. The opinion, however, at no poimt addressed the merits of using hists of eligible jurors. Similarly, despite California's directive that the that jurors "be selected at random froin a fair cross section of the population of the area served by the court," the himitation of service to "qualified persons"49 agam invites a conclusion that the hist of eligible jurors would serve as the best basis for coinparison. ${ }^{50}$

Havimg determined what data to allow for purposes of comparison, courts next face the challenge of interpretimg and determining the relative rehability of such data. The general impulse in both federal and state courts has been to avoid the use of per se formulas. ${ }^{51}$ This is not to say that courts have been hostile to statistical decision theory. On the

43. Efforts to assert such a right were rejected as early as 1879 in Virginia v. Rives, 100 U.S. 313, 322-23 (1879); accord Thiel v. Southern Pac. Co., 328 U.S. 217, 220 (1946).

44. See Taylor v. Louisiana, 419 U.S. 522, 538 (1975).

45. See Swain v. Alabana, 380 U.S. 202, 208-09 (1965).

46. See Gewin, Jury Selection, supra note 41 , at 830 (citing cases).

47. See, e.g., United States v. Butera, 420 F.2d 564, 569 n.13 (1st Cir. 1970). Judge Gewin suggests that the use of general population figures should require a showing of greater disparity, since "population may not account for certain inponderables which would dilute the number of presumptive eligibles in a cognizable class." Gewin, Jury Selection, supra note 41, at 833.

48. 439 U.S. at 365 n.23.

49. CAL. Civ. Proc. Code $\S 197$ (West 1982).

50. Harris did little to clarify the theoretical issues involved in determining what variety of comparison should be permitted. See infra notes $166-67$ and accoinpanying text.

51. Judge Gewin speculated in some detail about the possibility of abstracting a generally compelling statistical standard from Swain, Gewin, Jury Selection, supra note 41 , at 828-36, but he stopped short of concluding that statistical evidence alone should or does suffice to establish a prima facie case, id. at 820-30. 
contrary, encouraged by the scholarly literature, ${ }^{52}$ they have relied increasingly upon refined probability theory..$^{53}$ Nevertheless, the variety of methodologies available, as well as the distortions resulting from the exercise of peremptory cliallenges, ${ }^{54}$ have prevented this rehance from becoming formulaic.

iii. The systematic exclusion requirement. The third element to be established in support of a prima facie challenge to venire composition is a systematic exclusion. The underrepresentation of a cognizable group must have resulted from a procedural feature "inherent in the particular jury-selection process utilized." 55 Both federal and state law will infer a systematic flaw only from significant underrepresentation on a number of previous venires. ${ }^{56}$ This pohicy presumably reflects a conviction that an individual instance of underrepresentation might be a coincidence, whereas a pattern will betray a systematic procedural abuse. ${ }^{57}$ Rather than being entitled to a cross-sectional venire, then, the challenger lias a right only to a fair chance, based on random draw, of having a jury drawn from a representative panel. At this stage the paramount concern is procedural detachment.

\section{c. Venire Composition: The Burden of Rebuttal}

In Hoyt v. Florida, ${ }^{58}$ the Supreine Court rejected an equal protection challenge to the Florida practice of exempting women from jury service unless they registered as willing to serve. The Court specifically lield that the resulting disproportion on venires could be justified if the exemption were "based on some reasonable classification [that rested] on some rational foundation." 59 In accordance with this rational-basis burden of

52. See, e.g., Beale, Integrating Statistical Evidence and Legal Theory to Challenge the Selection of Grand and Petit Jurors, 46 LAW \& CoNTEMP. ProBs., Autumn 1983, at 269, 276-77; Finkelstein, The Application of Statistical Decision Theory to the Jury Discrimination Cases, 80 HARV. L. REV. 338 (1966); Kairys, Juror Selection: The Law, a Mathematical Method of Analysis, and a Case Study, 10 AM. CRIM. L. Rev. 771, 785-89 (1972); Kairys, Kadane \& Lehoczky, Jury Representativeness: A Mandate for Multiple Source Lists, 65 CALIF. L. REV. 776, 778-802 (1977); Sperhich \& Jaspovice, Statistical Decision Theory and the Selection of Grand Jurors: Testing for Discrimination in a Single Panel, 2 Hastings CONST. L.Q. 75 (1975); Coinment, The Civil Petitioner's Right to Representative Grand Juries and a Statistical Method of Showing Discrimination in Jury Selection Cases Generally, 20 U.C.L.A. L. REv. 581, 620-31 (1973).

53. See, e.g., Castaneda v. Partida, 430 U.S. 482, 488 n.8, 496 n.17 (1977); Alexander v. Louisiana, 405 U.S. 625, 630 n.9 (1972).

54. See Finkelstein, supra note 52, at 352. The court in Wheeler specifically questioned the usefulness of statistieal decision theory to resolve a challenge posed in the course of voir dire. 22 Cal. 3d at 280, 583 P.2d at 763-64, 148 Cal. Rptr. at 905.

55. Duren, 439 U.S. at 366.

56. Id.

57. See Gewin, Jury Selection, supra note 41 , at 828 (citing cases).

58. 368 U.S. 57 (1961).

59. Id. at 61 . 
rebuttal, ${ }^{60}$ the Court accepted as sufficient its own conclusion that the scheme might reasonably serve unspecified public pohicy goals or administrative convenience. ${ }^{61}$

By contrast, the Court in Taylor declared that under the sixth amendment a slowing of rational grounds for a cross-section violation cannot rebut a prima facie case. ${ }^{62}$ Duren further indicated that such a violation will be approved only if it serves a "significant state interest ... Inanifestly and primarily advanced by those aspects of the juryselection process, sucli as exeinption criteria, that result in the disproportionate exclusion of a distinctive group." ${ }^{33}$ Notwithstanding the fundamental nature of the right to criminal trial by an impartial jury, the burden of rebuttal is thus less taxing than under the traditional strictscrutiny standard, which requires a showing that the violation serves a coinpelling state interest and that no less onerous alternatives exist for achieving the state's end. ${ }^{64}$ The California Suprente Court adopted the Duren standard in Harris, ${ }^{65}$ although it intimated that only a "compelling justification" can legitimize what would otlerwise be an unacceptable procedure. ${ }^{66}$

\section{d. Voir Dire: The Sixth Amendment Standard}

Both counsel and the court exercise a necessary element of discretion in the process of striking veniremembers. Thus the standard for the earlier stages of selection, witl its emphasis on randomness, cannot apply. A majority of courts accordingly have concluded that the sixth amendment's cross-section requirentent does not extend to voir dire. ${ }^{67}$ The Supreine Court has yet to articulate a sixth amendment standard specifically applicable to voir dire, and most cliallenges liave been judged

60. For an elaborate illustration of how favorable this standard is to the government, see Williamson v. Lee Optical, 348 U.S. 483 (1955).

61. Hoyt, 368 U.S. at 63.

62. Taylor, 419 U.S. at 534.

63. Duren, 439 U.S. at 367-68.

64. See, e.g., Shapiro v. Thompson, 394 U.S. 618, 634, 637-38 (1968).

65. People v. Harris, $36 \mathrm{Cal}$. 3d at 59, 679 P.2d at 446, $201 \mathrm{Cal}$. Rptr. at 795.

66. Id. at $45-46,679 \mathrm{P} .2 \mathrm{~d}$ at $437,201 \mathrm{Cal}$. Rptr. at 786 .

67. See, e.g., United States v. Clark, 737 F.2d 679 (7th Cir. 1984); United States v. Thompson, 730 F.2d 82, 85 (8th Cir.), cert. denied, 105 S. Ct. 443 (1984); United States v. Childress, 715 F.2d 1313, 1319-20 (8th Cir. 1983) (en banc), cert. denied, 104 S. Ct. 744 (1984); Weathersby v. Morris, 708 F.2d 1493, 1497 (9th Cir. 1983), cert. denied, 104 S. Ct. 719 (1984); People v. Williams, 97 Ill. 2d 252, 273-80, 454 N.E.2d 220, 229-33 (1983), cert. denied, 104 S. Ct. 2364 (1984); see also Saltzburg \& Powers, Peremptory Challenges and the Clash Between Impartiality and Group Representation, 41 MD. L. REv. 337, 360 (1982); Comment, The Defendant's Right to Object to Prosecutorial Misuse of the Peremptory Challenge, 92 Harv. L. REv. 1770, 1780 (1979). But see Grigsby v. Mabry, 569 F. Supp. 1273, 1285-86 (E.D. Ark. 1983); State v. Neil, 457 So. 2d 481 (Fla. 1984); Commonwealth v. Soares, 377 Mass. 461, 483-87, 387 N.E.2d 499, 513-15 (1979); State v. Crespin, 94 N.M. 473, 612 P.2d 716 (1980); Note, Limiting the Peremptory Challenge: Representation of Groups on Petit Juries 86 YALE L.J. 1715, 1731-32 (1977). 
either under the fourteenth amendment standard developed im Swain or the later state-court variations. ${ }^{68}$ Since the Court has accepted certiorari in Batson v. Kentucky-a case specifically alleging a sixth amendment violation in voir dire-the current uncertainty should soon be resolved. ${ }^{69}$

Two years before agreeing to consider Batson's appeal, the Court rejected a similar petition in $\mathrm{McCray}$ v. New York, ${ }^{70}$ relnarking that "other courts" should first consider and define the issues. ${ }^{71}$ This invitation was most likely directed to state supreme courts, which were relying on state constitutions to modify Swain's requirement that a challenger establish an historical abuse of pereinptories. Nevertheless, a New York district court accepted the offer in a habeas corpus action arising from the very case that the Supreme Court had refused to hear. In McCray v. Abrams, ${ }^{72}$ the Second Circuit affirmed the district court holding and articulated a distinct sixth amendment standard for voir dire. McCray $v$. Abrams thus had the practical effect of overruling Swain from below. ${ }^{73}$ The court in McCray v. Abrams based its allocation of burdens on an analysis of the theoretical justifications for the cross-section requirement:

If there is a Sixth Amendment requirement that the venire represent a fair cross section of the community, it must logically be because it is important that the defendant have the chance that the petit jury will be similarly constituted. The necessary implication is that the Sixth Amendment guarantees the defendant that possibility. It guarantees not that the possibility will ripen into actuality, but only the fair and undistorted chance that it will. We thus agree that the Sixth Amendment does not require any action to ensure that the representative character of the venire be carried over to the petit jury; we think the Amendment simply prohibits the state's systematic elimination of the possibility of such a carry-over. ${ }^{74}$

The court next considered what might constitute a "systematic elimination" of the possibility of maintaining a cross section in voir dire. Beginning with the test set forth in Duren, it concluded that the second prong, which requires that a cognizable group's representation be "fair and reasonable in relation to the number of such persons in the commu-

68. See infra notes 116-39 and accompanying text.

69. See supra note 13

70. 461 U.S. 961 (1983).

71. Id. at 962 (plurality opinion).

72. 750 F.2d 1113 (2d Cir. 1984).

73. At the theoretical level, the decision merely articulated an alternative standard for handling challenges to the exercise of peremptories. If upheld, however, McCray would totally supplant Swain, since the more rigorous requirements for establishing a prima facie case under the fourteenth amendment would apply exclusively to convictions obtained before the sixth amendment was incorporated into the fourteenth amendment in Duncan. See DeStefano v. Woods, 392 U.S. 631 (1968) (denying Duncan retroactive effect).

74. $M c$ Cray, 750 F.2d at $1128-29$. 
nity," could not be "relevant and material" at this stage. 75

The court's reasoning, if perhaps not its conclusion, seems open to question. Duren did not establish that a venire must represent a cross section of the community, but nerely that the selection of veniremembers must be random, so that the pattern of venires over time will be representative. The inappropriateness of applymg the second prong in voir dire, then, arises not from the fact that voir dire potentially compromises representativeness, since that potential inheres in venire selection as well. It arises, rather, from the fact that pereinptory challenges are presuinably nonrandom.

Had the court focused on this distinction, it could have provided a far more conpelling reason than it did for dispensing with Swain's requirement that a defendant challenging the use of peremptories establisli a pattern of abuse over a significant period of time. The court justified abandoning the history-of-abuse requirement inerely by noting that the sixth amendinent extended the interest im impartiality to "all criminal prosecutions."76 McCray might better have stressed that statistical evidence is of limited value when reviewing a nonrandom discretionary proceeding, since proof of abuse over time cannot riglitly be considered a necessary eleinent for establishing an abuse of discretion in a particular instance.

The first and third prongs of Duren together require a showing that a cognizable group has been systematically excluded. McCray adapted these prongs to the discretionary context of voir dire by declaring that an impermissible exclusion will have occured if a "substantial likelihood" exists that veniremembers were struck because of their group affiliation. ${ }^{77}$ The court further announced that once a prima facie case has been inade, "the burden of proof shifts to the State to rebut the presuinption of unconstitutional action by showing that permissible racially neutral selection criteria and procedures have produced the monochromatic result." ${ }^{\text {"78 }}$ Within the discretionary context of voir dire, selection criteria are permissible only to the extent that they are properly inotivated. Courts consequently focus on whether counsel directing the peremptory challenges reasonably believed that a prospective juror might be biased in ways that could not support a challenge for cause. ${ }^{79}$ The outcome will

75. Id. at 1131 .

76. Id. at 1130. This cryptic explanation leaves unaddressed the contention in Swain that a violation cannot be effectively established on the basis of the limited statistical evidence available in a single case.

77. Id. at 1131-32.

78. Id. at 1132 (quoting Castaneda y. Partida, 430 U.S. 482,494 (1977), which quoted Washington v. Davis, 426 U.S. 229, 241 (1976), which quoted Alexander v. Louisiana, 405 U.S. 625, 632 (1972)). For a discussion of the standards proposed in these cases, see infra notes 87-115.

79. $M c$ Cray, 750 F.2d at 1132 . 
turn on motivations reasonably imputed to counsel, rather than on mechanical procedural elements and the effects of their operation.

$M c C r a y$ thus radically modified Duren by finding "systematic" exclusion in an indivudual abuse of discretion. As the dissent trenchantly reınarked, this notion of "systentatic" strains the meaning of the term as used in Taylor and Duren. It also runs counter to the apparent conviction of at least five other circuits that Swain's pattern-of-abuse requireinent is essential to a showing of "systenıatic" flaws. ${ }^{80}$ Here again, the court might better have stressed the nonrandoin, individualized nature of voir dire proceedings. The third prong of the Duren test with its system-wide focus is simply not apphicable. ${ }^{81}$

\section{e. Voir Dire: The Fourteenth Amendment Standard}

i. The prima facie case. With the exception of McCray, the case law regulating voir dire has affirmed the standard developed under the fourteenth amendnient. In Swain, the only Supreine Court decision addressing voir dire, a black defendant was convicted and sentenced to death by an all-white jury for raping a white wonıan. Swain introduced evidence that no black had served on a petit jury since 1950 . Nevertheless, the Court held that he had not established a prima facie case, basing this conclusion on a presumption that the prosecutor has used perentptory challenges to obtain an impartial jury. The Court reınarked that not even a challenge based on group affiliation would compromise fairness, since all groups are subject to similar challenge. ${ }^{82}$ This analysis proceeds directly froin an acceptance that the term "pereinptory" means what it says. ${ }^{83}$ Only when the use of peremptories has been documented as having worked to a group's disadvantage over a significant period of time

80. For a listing and annotation of these cases, see id. at 1136 (Meskill, J., dissenting).

81. The Second Circuit's attempt to defuse Swain by distinguishing the sixth from the fourteenth amendinent standard is not without precedent. In People v. Payne, 99 Ill. 2d 135, 457 N.E.2d 1202 (I983), cert. denied, 105 S. Ct. 447 (1984), the Illinois Supreme Court reversed a lower court decision virtually identical to that in McCray v. Abrams. The primary difference between the short-lived Illinois standard and that proposed in $M c C r a y$ is that the former required only a reasonable appearance, rather than a "strong likelihood," that the state's pereinptories lad been exercised on the basis of group affiliation.

Payne's sixth amendment analysis in turn resembles that indirectly proposed in an earher New York state case, People v. Thoinpson, 79 A.D.2d 87, 435 N.Y.S.2d 739 (1981). In Thompson, the New York Appellate Division quashed a jury following a prosecutor's use of all his peremptories against blacks. While the defense's mitial inotion for mistrial was founded on the state constitution, the court pointedly remarked that $S$ wain had been decided on equal protection grounds, whereas the current case imvolved a distinct sixth amendment claim. 79 A.D.2d at 93-94, 435 N.Y.S.2d at 745. In its reliance on the state constitution, Thompson appears to have been silently overruled in People v. McCray, 57 N.Y.2d 542, 443 N.E.2d 915, 457 N.Y.S.2d 441 (1982), which upheld Swain and prepared for the habeas corpus petition resolved in contrary fashion by the Second Circuit.

82. Swain, 380 U.S. at 221 .

83. See id. at 221-22. 
will a particular discrepancy be held to reflect a systematic flaw-one based on an impermissible policy of perverting the legitimate purposes of the procedural device. ${ }^{84}$

The difficulty in overcoming the presumption of fair use is reflected in the Court's standard for a prima facie case. In order to support a "reasonable inference" that blacks are being denied their "right and opportunity to participate in the administration of justice," a challenger must show that "the prosecutor in a county, in case after case, whatever the circunistances, whatever the crime and whoever the defendant or the victim may be," has peremptorily challenged qualified blacks who have not been successfully challenged for cause, with the effect that no blacks ever serve on petit juries. ${ }^{85}$ Predictably, Swain could not ineet this burden, and virtually no other defendant has succeeded in meeting it since. ${ }^{86}$

ii. The burden of rebuttal. Swain did not articulate a standard for rebuttal, simce the challenger failed to make a prima facie case. Subsequent cases have omitted extensive discussion of rebuttal for the same reason.

The state's burden in meetimg challenges based on disproportionate impact has been generally defined, however, im the context of pre-Duncan venire-selection cases and in challenges to the composition of state grand juries. ${ }^{87}$ These definitions are contradictory. In order to appreciate both the source of this problem and its likely implications for rebuttal in voir dire, it is necessary briefly to review the requirements for a prima facie case under the fourteenth ainendment.

In the earlier stages of juror selection-the venire and the jury wheel itself-the elements of a prima facie case under the fourteenth amend-

84. Id. at 223-24. Swain never explained how a legitimate challenge could become illegitimate by a too-frequent exercise.

85. Id.

86. For a discussion of some representative subsequent challenges and their results, see McCray, 750 F.2d at 1120 n.2.

87. Although the right to a grand jury has not been declared fundamental and therefore is not binding on the states through the fourteenth aunendment, once a state determines to use an indictment system a defendant has a fundamental interest in having his grand jury drawn from a representative cross section of the community. Alexander v. Louisiana, 405 U.S. 625, $635-36$ (1972) (Douglas, J., concurring). In Alexander, Justice White observed that "[t] he principles that apply to the systematic exclusion of potential jurors on the ground of race are essentially the same for grand juries and for petit juries . . . ." Id. at $626 \mathrm{n} .3$. In his concurrence, Justice Douglas quoted Justice Black in approving this sentiment: "Indictment by Grand Jury and trial by jury cease to harmonize with our traditional concepts of justice at the very moment particular groups, classes or races . . . are excluded as such froin jury service.' " Id. at 636 (quoting Pierre v. Louisiana, 306 U.S. 354, 358 (1939)). In reflecting on why this right is deemed fundanental once it attaches, one can focus either on the juror's equal protection interest, as does Justice Black, or on the defendant's due process interest. In terms of the latter interest, cross-sectionality cannot be considered an end in itself, since information jurisdictions dispense with the grand jury requirement altogether. In the context of both grand and petit jury venire selection, then, the cross-section requirement is considered a necessary means to achieve inpartiality. 
ment standard, which still applies to grand jury challenges, and the sixth amendment standard, which controls petit jury selection, are in all essential respects identical. ${ }^{88}$ The elements of a prima facie case under the fourteenth amendinent approached the Duren standard only gradually, however. Starting from an early proscription of facially discriminatory racial criteria, ${ }^{89}$ the standard then moved through an acceptance of evidence of disproportionate impact combined with an opportunity on the part of selection officials to exercise discretion against the cognizable group..$^{90}$ Finally, Castaneda v. Partida ${ }^{91}$ removed the requirement that the challenger prove that the selection officials had an opportunity to discriminate. ${ }^{92}$

By abandoning this element of the prima facie case, Castaneda further distanced jury composition cases froin the fourteenth amendment purpose-norm cases of which they had always been considered a subset. The purpose norm requires a challenger to show not only a policy's disproportionate impact but also the pohicy's authors' specific intent to produce that effect. ${ }^{93}$ In Arlington Heights v. Metropolitan Housing Corp., ${ }^{94}$ the Supreme Court offered exainples of evidence that might support an inference of such intent: a background of discrimination, an incriminatmg sequence of events, departures from normal procedure, a suspicious legislative or administrative history, and revealing testimony by the decisionmakers. ${ }^{95}$

Nevertheless, Arlington Heights and Washington v. Davis distinguished the standard applicable to jury selection, ${ }^{96}$ suggesting that cases inarked by an egregious disparity belong in the category created in Yick Wo v. Hopkins. ${ }^{97}$ In Yick Wo, officials administered a facially neutral ordinance to discriminate against Chinese. The Supreme Court held that the extent of the impact warranted a conclusive inference that officials had purposely exercised their discretion to discriminate against the excluded group. The Court in Arlington Heights abstracted from this case the principle that "[s]oinetimes a clear pattern, unexplainable on

88. The only potential difference consists in the fact that cognizability in a grand jury challenge may be defined in terms of whether the group has been "singled out for different treatment under the laws, as written or apphed." Castaneda, 430 U.S. at 494 (citing Hernandez, 347 U.S. at 478-79).

89. See, e.g., Cassell v. Texas, 339 U.S. 282 (1950); Hernandez, 347 U.S. at 477; Strauder v. West Virgiria, 100 U.S. 303 (1880).

90. See, e.g., Alexander, 405 U.S. at 629-32.

91. 430 U.S. 482 (1977).

92. Id. at 494 .

93. Washington v. Davis, 426 U.S. 229, $240-42$ (1976).

94. 429 U.S. 252 (1977).

95. Id. at $267-68$.

96. The Court in Davis observed that "in the selection of juries . . . the systematic exclusion of Negroes is itself such an 'unequal apphication of the law ... as to show intentional discrimination." " 426 U.S. at 241-42 (quoting Akins v. Texas, 325 U.S. 398, 404 (1945)).

97. 429 U.S. at 266 n.13 (citing Yick Wo, 118 U.S. 356 (1886)). 
grounds other than race, emerges from the effect of the state action even when the governing legislation appears neutral on its face." 98 In a footnote to this remark, the Court suggested that some of the jury-selection challenges clearly fall within this category; in others, it continued, " $[\mathrm{b}]$ ecause of the nature of the jury selection task . . . , we have pernitted a finding of constitutional violation even when the statistical pattern does not approach the extremes of Yick Wo . . . ."99

The courts have never really specified what in a jury challenge warrants distimguishing it from every other constitutional claim founded on a showing of disproportionate impact. This fourteenth amendment treatment characterizmg the challenger's interest as particularly fundamental seems to conflict with the sixth amendment approach, which protects the challenger's interest by intermediate, rather than strict, judicial scrutiny. Despite this apparent theoretical conflict, the practical result is to impose the same burden under either standard for establishing a prina facie case: the "rule of exclusion" enables a challenger in a fourteenth amendment case to rely on a showing of significant disproportion alone, as if he were proceeding under the sixth amendment. ${ }^{100}$ Because of the rule of exclusion, the Arlington Heights distimction between Yick Wo cases and those marked by lesser disproportion has no significance for the prima facie case. However, the Court's imsistence on drawing this distinction invites speculation that there 1might be a variance within the fourteenth amendment standard unrelated to the challenger's burden.

One possibility is that the government's burden may vary with circumstances im rebutting a prima facie case under the fourteenth amendment. Yick Wo imvolved disproportionality accompamed by the opportunity to exercise administrative discretion. To this extent it resembles the opportunity-to-discriminate cases among jury challenges, including those alleging abuse of peremptories. The standard for rebuttal in such cases, while rarely identified as distinctive, often approxinnates the sixth amendment approach, which focuses on effects rather than motives. In Alexander v. Louisiana, ${ }^{101}$ for instance, the Court declared that upon a prima facie showing "the burden of proof shifts to the State to rebut the presumption of unconstitutional action by showing that permissible racially neutral selection criteria and procedures have produced the monochroniatic result." 102 The Court further unequivocally dismissed a purpose-oriented analysis. It declared not only that "affirnations of good faith im nraking imdividual selections are imsufficient to dispel a prima

98. Id. at 266 .

99. Id. at $266 \mathrm{n} .13$.

100. See Castaneda, 430 U.S. at 494.

101. 405 U.S. 625 (1972).

102. Id. at 632 . 
facie case of systematic exclusion," but also that "the result [can bespeak] discrimination, whether or not it was a conscious decision on the part of any individual jury commissioner." "103 This formulation suggests that neither affirmations of good faith nor proof of innocent purpose will suffice as a rebuttal in such cases, for the offense consists im having constructed a system that has allowed for a demonstrated discrimination regardless of intent. Under this regime, then, a prima facie showing of a Swain violation would preclude rebuttal testimony establishing a prosecutor's proper motive in the exercise of peremptories. ${ }^{104}$

It is far from certain, however, that courts will consistently apply this standard when judging a system that affords an opportuinty to discriminate. It is also unclear whether courts will apply a different standard when judging systems that deny officials discretionary power to choose among prospective jurors. One might argue that a Yick Wo presunption of systematic disproportion should be held irrebuttable not because the disproportion is so great, but rather because it occurred within a system that allows discrimination. Indeed, this proposition may explain the suggestion in Alexander that when an opporturity exists to discriminate, neither protestations nor actual proof of good faith will suffice. ${ }^{105}$

On the other hand, cases other than those involving challenges based on the opportunity to discriminate suggest that purpose remains a significant rebuttal elenient in all fourteenth ainendment jury challenges. In the course of its sixth amendment analysis, for instance, Duren distnignished the fourteenth amendment jury challenges, including those mvolving exercises of official discretion:

In the cited cases [ironically, all challenges involving an opportunity to discriminate], the significant discrepancy shown by the statistics not only indicated discriminatory effect but also was one form of evidence of another essential elenient of the constitutional violation-discriminatory purpose. Such evidence is subject to rebuttal evidence either that discriminatory purpose was not involved or that such purpose did not have a determinative effect. [Citations omitted.] In contrast, in Sixth Amendmient fair-cross-section cases, systeniatic disproportion itself denonstrates an infrimgenent of the defendant's interest in a jury chosen fronl a fair con1-

103. Id. (quoting Hernandez, 347 U.S. at 482 ).

104. The Court in Swain distinguished peremptory challenge cases from other fourteeuth amendment challenges involving an opportunity to discriminate because defense counsel may themselves have helped fashion the monochromatic result through their own exercise of peremptories. The challenger was consequently charged not only with documenting a significant disproportion over time, but also with establishing that this disproportion arose from the prosecutor's challenges. Swain, 380 U.S. at 224-26. The umiqueness of this burden on the challeuger in making a prima facie case should not logically affect the burden of rebuttal.

105. The proposition does not explain why the Court in Davis quoted precisely this formulation as applicable in all disproportionate impact cases. See Davis, 426 U.S. at 421. 
munity cross section. The only remaining question is whether there is adequate justification for this infringement. ${ }^{106}$

Thus, the Duren court appears unimpressed with the fact that Alexander expressly ruled out the possibility of rebuttal by "evidence . . . that discriminatory purpose was not involved."107 One cannot say authoritatively which standard apphes and when.

To further coinphicate matters, it is debatable whether a showing that a purpose to discriminate "did not have a determinative effect" will serve as an adequate rebuttal under either standard. In Duren, the Court cited as authority for its definition two sources: Castaneda and Mount Healthy City Board of Education v. Doyle. ${ }^{108}$ Castaneda, in fact, at no point suggested that either an absence of discriminatory purpose or that purpose's lack of effect would suffice as a rebuttal. This is not surprising: Castaneda is clearly an opportunity-to-discriminate case, which reproduced the Alexander standard verbatim. ${ }^{109}$ Mount Healthy, which did not concern a jury challenge, did support the two alternative Duren elements, but it did so in a way that will not likely supplant inore consistent standards. ${ }^{110}$ The curious standard for rebuttal proposed in the Duren footnote suggests that "purpose" may be a niere term of art favoring the state in rebuttal, just as it favors the challenger earher. In support of a fourteenth amendment prima facie case, statistics can establish ill inotive, good motive notwithstanding; at the stage of rebuttal, by contrast, Duren suggests that even ill motive might be forgiven, and a policy promoting disproportion approved, if the acknowledged purpose imight not have determined the pohicy's results.

The Duren standard of rebuttal in a voir dire challenge is constitutionally indefensible. It may be consistent under either strict or intermediate scrutiny to allow the state to rebut a prima facie case by establishing an absence of discriminatory purpose. It is niconsistent with

106. Duren, 439 U.S. at $368 \mathrm{n} .26$ (emphasis added). The burden of providing "adequate justification" as called for in the closing sentence can be met by "showing attainment of a fair cross section to be incompatible with a significant state imterest." Id. at 368.

107. Id. at 368 n.26.

108. The specific references made in Duren, 439 U.S. at 368 n.26, were to Castaneda, 430 U.S. at 493-95, and Mount Healthy, 429 U.S. 274, 287 (1977).

109. Castaneda, 430 U.S. at 494.

110. The Court declared that the challenger in this specific case was required to establish that the objective of frustrating his constitutionally protected conduct was a "motivating factor" in the decision to terminate his employment. 429 U.S. at 287 (quoting Arlington Heights, 429 U.S. at 270). In explaining the term "Inotivating factor," the Court in Arlington Heights suggested tliat a petitioner's success in making a prima facie case "would . . . have shifted to the [respondent] the burden of establishing that the same decision would have resulted even had the impermissible purpose not been considered." 429 U.S. at 270-71 n.21. The logic of this construction is elusive, since one can easily envision being inotivated to act by an impermissible purpose while nonetheless achieving a conceivably permissible effect. While mere dictum in Arlington Heights, this baffling standard was actually invoked as a basis for decision in Mount Healthy. 
established constitutional principles, however, to condone a specifically intended discriminatory effect simply by speculating that the state might not claim major credit for having realized its end. ${ }^{11}$ Moreover, in allowing the state to rebut a prima facie case inerely by deinonstrating that the effect might have resulted from a permissible purpose, the courts have adopted the lowest standard of review-a "rational basis" test. Under this standard, the state can meet its burden by offering any explanation that relates the discrimination to a legitimate government objective. ${ }^{12}$

Thus, Duren involves a basic contradiction: it allows a rational-basis rebuttal in cases that should be governed by a higher standard of review. ${ }^{113}$ As is reflected in the rule of exclusion, which significantly lowers the challenger's imitial burden, the right involved in such challenges has always been considered fundamental. ${ }^{114}$ To create such a powerful nondeference interest ouly to sanction its comproimse on a

111. This is the standard expressed in Arlington Heights, however. See supra note 110 and accoinpanying text.

112. See supra note 60 and accoinpanying text.

113. Professor Robert Cole has persuasively criticized efforts to justify the lower standard by common law analogies. In tort law, for instance, a negligent defendant can escape liability if it appears that plaintiffs injury would have occurred anyway. Professor Cole suggests that government reliance on such a defense should be proscribed for a variety of reasons. In the first place, there is a unique public policy value in maintaining the government completely above suspicion of racial prejudice. To avoid purishing the government when it admits racial prejudice, but denies that it proximately caused the injury, would undermine that value altogether. "The purpose rule prohibits specifically intentional discrimination, and for the courts to give effect to such a discriminatory decision seeins inconsistent with the need for the government to learn from and to be disciplined for its violation." R. Cole, Meinorandum for Constitutional Law II, Boalt Hall School of Law, University of California, Berkeley 1-2 (October 5, 1984).

Professor Cole further suggests that the Arlington Heights footnote departs from the courts' traditional refusal to speculate in a defendant's favor when the suspect conduct is patently antisocial. Id. at 2. Since purposeful racial discrinination is socially indefensible, it should warrant no favorable speculation whatsoever. Id.

Finally, Professor Cole questions the appropriateness in this context of the tort law arguinent that "it would have happened anyway." Id. In the usual tort case, history has recorded the injury and the only issue is assignment of liability. Id. In the context of jury selection, however, history can be effectively reconstructed simply by refusing to recognize the legitimacy of the tainted proceeding.

114. See supra note 100 and accompanying text. One might argue that the rule of exclusion operates not because the challenger's nondeference interest is so inherently strong, but rather because he has already proved in the course of establishing cognizability the added element required under the purpose norm-in this case, historical discrimination in the laws as written or applied. See Columbus Bd. of Educ. v. Penick, 443 U.S. 449 (1979) and Dayton Bd. of Educ. v. Brinkman, 443 U.S. 526 (1979) (establishing that a showing of prior discrimination coupled with a showing of current disproportion will constitute a prima facie case). The only remaining requirement, according to this objection, would be a showing of siguificant disproportion. This argument, however, iguores a crucial point: the history of discrimination allowed as added proof under the purpose norm traditionally must have been committed by the challenged governmental entity, see Swann v. Charlotte-Mecklenburg Bd. of Educ., 402 U.S. 1 (1971). This history, however, is not a requirement for establishing cognizability under fourteenth amendinent analysis. 
presentation of palpable, but potentially plausible, fictions is a perversion of traditional doctrine. ${ }^{115}$ In the context of voir dire, this confusion compounds the effects of a virtually msurmountable standard for a prima facie case.

Nevertheless, given the variety of unabandoned standards discussed above, it is far from certain that the Duren formulation is dispositive. The significance in a jury selection challenge of showimg an opportunity to discriminate also remams unclear. While such a showing is not an element of the prima facie case, it may alter the state's burden in rebuttal.

\section{f. Voir Dire: State Court Modifications of Swain}

In People v. Wheeler, ${ }^{116}$ the first case challenging Swain on any grounds, the Califorina Supreme Court objected to the suggestion that prosecutorial abuse could not be remedied unless sufficient instances had accumulated to constitute a pattern. ${ }^{117}$ While retaining Swain's presumption that peremptories have been properly exercised, ${ }^{118}$ the court in Wheeler redefined the elements of a prima facie case im a manner that anticipated the $M c C r a y$ sixth anendment standard. ${ }^{119}$ It held a challenger need only estabhsh a "strong likelihood" that officials struck members of a cognizable group from a particular panel because of their "group association," based on "as complete a record of the circumstances as is feasible." 120 The court histed a number of relevant factors: the proportion of available group members struck, the proportion of peremptories used to strike them, the range of characteristics among the stricken group members, the absence or perfunctory nature of examination in voir dire, and the defendant's relation to the group itself. ${ }^{121}$

The court in Wheeler shows a stronger inclination than the court in $M c C r a y$ to justify the state's burden im terins of the cross-section principle. After a prima facie showing, the state inust establish that peremptories were not exercised solely on the basis of "group bias." However, this showing need not be sufficient to have supported a challenge for cause. ${ }^{122}$ The Califonia Supreine Court appropriated Taylor's sanguine conception that common sense and consensus comcide, and that both approxi-

115. A further, less significant, confusion arises from the fact that many cases are apparently based on a piggybacking of interests, with the defendant alleging a violation of his due process interests based on a prior violation of the excluded group menbers' equal proteetion interest in serving. While one might assune that the defendant's claim therefore should be described as a due process violation, this often is not the case. See supra notes 10-11 and accompanying text.

116. 22 Cal. 3d 258, 583 P.2d 748, 148 Cal. Rptr. 890 (1978).

117. Id. at 285,583 P.2d at $767,148 \mathrm{Cal}$. Rptr. at 908-09.

118. Id. at $278,583 \mathrm{P} .2 \mathrm{~d}$ at $762,148 \mathrm{Cal}$. Rptr. at 904.

119. See supra notes $70-80$ and accompanying text.

120. 22 Cal. 3d at 280, 583 P.2d at 764, 148 Cal. Rptr. at 905.

121. Id. at 280-81, 583 P.2d at 764, 148 Cal. Rptr. at 905-06.

122. Id. at $281-82,583 \mathrm{P} .2 \mathrm{~d}$ at $765,148 \mathrm{Cal}$. Rptr. at 906. 
mate impartiality. This assumption is most evident in the court's distinction of "specific" from "group bias." Specific bias, the court suggested, may derive "from personal experience or from general exposure to pretrial publicity."123 As sucl, it constitutes a legitimate basis for either a peremptory challenge or a challenge for cause. Group bias, by contrast, is a permissible phenomenon apparently arising from something other than "personal experience," and it is to be tolerated-if not encouraged-as essential to the "demographic balance" necessary "to achieve an overall impartiality." 124 Thus, Wheeler extends the cross-section requirement beyond the venire level in pursuit of jury, not systemic, impartiality. ${ }^{125}$

Because Wheeler limits counsel to challenges intended "to ehminate a specific . . . bias relating to the particular case on trial or the parties or witnesses thereto,"126 group bias is located beyond challenge as an acceptable variety of prejudice. Despite the practical and theoretical difficulties arising from this distinction, ${ }^{127}$ Wheeler goes far towards remedying Swain's insuperable standard for making a prima facie case.

A number of other states have followed California's lead, varying somewliat the scope of protection and the distribution of burdens. In Commonwealth v. Soares, ${ }^{128}$ the Massachusetts Supreme Judicial Court also rehed on its state constitution to modify the Swain standard. Soares began with the Wheeler presumption that peremptories liad been used properly. The court went on to require a two-part showing to establish a prima facie violation. First, the cliallenged jury members must belong to one of the "discrete" groups listed in the state's Equal Rights Amendment. Second, there must exist a "likelihood" that the exclusion was based solely on membership in the group. ${ }^{129}$ Tlie burden then slifts to the state to rebut the prima facie showing under a standard essentially identical to that in Wheeler. ${ }^{130}$ The major difference between the two approaches is that Massachusetts strictly defines the cognizable groups, while California requires a stronger mitial showing of disproportion.

More restrictive than Soares on the issue of cognizability, and similar to Wheeler in defining the weight of evidence required for an initial showing, is the recent case of State $v$. Neil, ${ }^{131}$ which marked Florida's

123. Id. at 274, 583 P.2d at 761, 148 Cal. Rptr. at 901.

124. Id. at 276, 583 P.2d at $761,148 \mathrm{Cal}$. Rptr. at 902.

125. Note that under this conception of jury impartiality, individual jurors need not be impartial.

126. Wheeler, 22 Cal. 3d at 274, 583 P.2d at 760, 148 Cal. Rptr. at 901.

127. See infra text accompanying notes 171-79.

128. 377 Mass. 461, 387 N.E.2d 499, cert. denied, 444 U.S. 881 (1979).

129. Id. at $488-90,387$ N.E.2d at 516-17.

130. Id. at 491,387 N.E.2d at 517.

131. 457 So. $2 \mathrm{~d} 481$ (Fla. 1984). 
break from Swain. Neil limited its holding to racial challenges, leaving open whether Swain would apply in other contexts. ${ }^{132}$ As in Wheeler, the Florida court called for evidence of a "strong likelilıood" that group affiliation triggered the use of peremptories. ${ }^{133}$ Neil not only stressed the importance of raising contemporaneous objections but also called for extraordinary deference on appeal to the findings of the trial judge, who alone is in a position to interpret tlie proceedings. ${ }^{134}$ Unlike the California and Massachusetts courts, the Florida court concluded that a significant nuniber of exclusions exercised against a cognizable group cannot in itself estabhish the requisite likelihood of a specific intent to discriminate. ${ }^{135}$

In this last conclusion, the Neil approach differs radically from that adopted in New Mexico. In State v. Crespin, ${ }^{136}$ the New Mexico Court of Appeals rehed on its state constitution to afford a challenger a clioice between the Swain standard of historical abuse and its interpretation of the "Wheeler-Soares rationale," by which "the absolute nuinber of cliallenges $\mathrm{m}$ one case [can raise] the inference of systeinatic acts by tlie prosecutor."137 One might question whetlier Crespin correctly construes tlie Wheeler decision: though the California Supreme Court did not expressly reject the possibility of finding reversible error on the basis of statistical evidence alone, it minimized tlie significance of such findings in interpreting tlie highly discretionary voir dire. ${ }^{138}$ Crespin, like Soares, represents an extreme state-court reaction against Swain. Both Massachusetts and New Mexico significantly qualify the discretionary element of voir dire by subjecting it to intensive statistical review. ${ }^{139}$

132. Id. at 487 .

133. Id. at 486. This burden is heavier than the "substantial likelihood" called for in People v. Thompson, 79 A.D.2d 87, 108, 435 N.Y.S.2d 739, 754 (1981). The reasoning of Thompson strongly influenced the court in Florida v. Neil, 454 So. 2d 481 (Fla. 1984). For further discussion of Thompson, see supra note 81.

134. Neil, 457 So. $2 d$ at 486; Thompson, 79 A.D.2d at 108-10, N.Y.S.2d at 753-55.

135. Neil, 457 So. $2 d$ at 487 n.10; Thompson, 79 A.D.2d at 110-11, 435 N.Y.S.2d at 755 . For an analysis approving this position see Comment, Survey of the Law of Peremptory Challenges: Uncertainty in the Criminal Law, 44 U. PITT. L. REv. 673, 688-90 (1983).

136. 94 N.M. 486, 612 P.2d 716 (Ct. App. 1980).

137. Id. at 488,612 P.2d at 718 . The suggestion that these alternatives constitute a meaningful choice cannot be taken seriously, since no challenger presented with these options would choose to proceed under Swain, which imposes not only a higher burden of proof on the challenger but also quite probably a lower burden of rebuttal on the state. See supra text accompanying notes 81-90.

138. Wheeler, $22 \mathrm{Cal}$. 3d at 279-80, 583 P.2d at 763, $148 \mathrm{Cal}$. Rptr. at 904-05.

139. This Comment will defer discussing the appropriateness of this reaction until the concludimg Sections. See infra text accompanying note 180. 
II

The Appropriate LIMITS of THE CROSS-SECTION PRINCIPLE IN JURY SELECTION

\section{A. The Fundamental Rights Argument Reconsidered}

No court has yet adopted a standard of review fully consistent with the accepted claim that the right to criminal trial by an impartial jury is fundamental. Under the fourteenth amendment standard apphed to grand jury selection, the suitably low burden for establishing a prima facie case may well be undermined by the confusion surrounding the burden of rebuttal in equal protection and due process challenges. ${ }^{140}$ Even if one rehes solely on Castaneda and so defines the burden of rebuttal in grand jury challenges as requiring proof of neutral selection procedures, rather than permissible motives, ${ }^{141}$ it remains unlikely that a compelling state interest is necessary to justify a nonneutral procedure. While the Supreine Court has not addressed this issue, it would be odd indeed if the standard for rebuttal in a grand jury challenge were to exceed the sixth anendment standard that controls in petit jury venire selection. The latter standard is consistent ouly with intermediate review. ${ }^{142}$ Moreover, with respect to voir dire, Swain imposes so high an imitial burden on the challenger that a discussion of rebuttal is largely acadenric. ${ }^{143}$ Although $\mathrm{McCray}$ lowered this burden in a sixth ainendment context, it then relied on a fourteenth amendinent formulation to define the burden of rebuttal. $^{144}$ State court inodifications of Swain admittedly both have lowered the challenger's burden of proof and adopted strict purpose norm standards for rebuttal. Thus, under Wheeler, Soares, and Crespin, the state must clearly dispel a presumption of specific intent to discriminate once the challenger establishes a primia facie case. ${ }^{145}$ However, no state has yet adopted a coinpelling-state-interest test for the earher stages of juror selection.

Such uncertainty about the fundainental nature of the right redirects one to Duncan, which delineated the strength of the challenger's interest in trial by impartial jury. In Duncan v. Louisiana, ${ }^{146}$ the Supreme Court justified applying the sixth ainendment to the states by suggesting not that the interests enumerated by Justice White are umiversally compelhing, but rather that they are "fundainental to the American scheme of

140. See supra notes 87-115 and accompanying text.

141. See Casteneda, 430 U.S. at 494 (quoting Alexander, 40 S U.S. at 632).

142. See supra notes $62-66$ and accompanying text.

143. See supra notes $82-86$ and accompanying text.

144. See supra notes $72-80$ and accompanying text.

145. See supra notes $116-39$ and accompanying text.

146. 391 U.S. 145 (1968). 
justice."147 This formulation unapologetically emphasizes the cultural and historical context of justice. The Court explamed that this approach to "fundamental" rights served not only to qualify, but to redefine, a term whose appropriateness for constitutional analysis had long been held to consist largely in its appeal to universal conditions of human dignity. Under previous analyses, the fundamental nature of a right was derived from its abstraction-its self-evident application to any systein, regardless of its structure, that embraces the principles of justice conceived by the common-law system. ${ }^{148}$ Duncan's msistence that it is procedures, rather than principles, that are fundaniental within a particular schenie thus seems both anomalous and soniewhat jaded, for it suggests that justice itself might finally be only a relative matter. ${ }^{149}$

In order to consider constitutionality within the context of an "actual system," as distinct from underlying principles, Duncan focused not on fundamental rights, but fundamental processes. The Court defined this term as designating particular customs "necessary to an AngloAmerican regime of ordered hberty." 150 This definition shifted attention from the common law conception of liberty whereby custouns are judged to the customs theniselves as touchstones of constitutionality. The Court concluded that a constitutional aniendnient describing a procedural custom might be enforced on the states solely because nunierous jurisdictions already accept that custom. ${ }^{151}$

By characterizing any bare recital of primciple as inadequate, the Court suggested that constitutional priorities must be arranged in relation to established nistitutions. The great hazard in this approach is that it renders both common law principles and common law procedures virtually self-vahidating. As a result, nistitutional entrenchment threatens to become a condition of constitutional interpretation, dictating the relative strength of various guarantees which the Franiers deliberately defined abstractly. Inquiry into whether a procedure is "necessary to an Anglo-American regime of ordered liberty" will proceed on a presuniption, indeterminately rebuttable, that "liberty" is an historical given, secured by enforcing procedures to the extent of their historical sanc-

147. Id. at 149 .

148. One thinks, for instance, of Justice Stone's vastly influential Carolene Products footnote, with its highly generalized suggestion that fundamental principles might require an antimajoritarian diligence in defending the rights of any isolated uninority. United States v. Carolene Prods. Co., 304 U.S. 144, 152 n.4 (1938).

149. That this reading of Duncan is not inerely alarmist is confirmed by the Court's explanatory footnote, which announced an intention to break from a tradition that treated "state crinninal processes" as "inaginary and theoretical schemes," rather than "actual systems bearing virtually every characteristic of the comınon-law systein . . . Duncan, 391 U.S. at 149 n.14. The Court thus suspects any appcal to principle that is not at the sane time an appeal to coinmon law practice.

150. Id.

151. Id. 
tion. ${ }^{152}$ Self-congratulation thus becomes a principle of constitutional interpretation, and institutional inertia is exalted by an act of deference to history. ${ }^{153}$

One wonders whether the reluctance actually to treat trial by jury as a fundamental interest arises froin an intuition that the process itself is finally not an indispensable signal of our culture's regard for due process of law. Indiscriminately exalting a process that is not in itself crucial to liberty adulterates the standard for protecting what is most valuable. In the wake of Duncan, the Court seems ever more ready to ignore what Justice Marshall stated so cogently in Peters: "[t] he due process right to a competent and impartial tribunal is quite separate froin the right to any particular form of proceeding."154 As a result, the right to due process itself has become attenuated. Our doubts about the fundamental necessity of this particular form of proceeding, reflected in weak and eccentric standards for review, have coinpromised our commitment to the basic principle of due process. Moreover, the confused standard for reviewing grand jury challenges suggests that this malignancy has spread to related processes. As Justice White observed in Alexander, while grand jury indictinent is not a fundamental procedural right, a defendant so indicted has a fundamental interest in having his jurors drawn from a representative panel. ${ }^{155}$ Nevertheless, the Court felt constramed by the petit jury selection cases to adopt a comparable standard, thereby treating this right as less than fundamental.

Thus, even though the judiciary appreciates the need to vigorously guard a defendant's interest in due process and impartial judgment, the question remams whether courts actually perceive cross-sectionality as a necessary condition of fair trial. The relative laxness of current standards for review may reflect an uncertainty which courts must resolve in order to formulate a principled standard for protecting indisputably fun-

152. Hence the Court described the fourth amendment's exclusionary rule as applying to the states not because it is a fundamental condition of privacy, but rather because our system historically requires it. Id. Likewise, the Court deemed as fundamental the policy barring a prosecutor from commenting on a defendant's refusal to testify not because the privilege against self-incrimination is essential to liberty, but rather because our system las committed itself to the concept. Id.

153. In its distaste for abstractions, the Duncan Court dismissed as too rarefied the following principled reasoning of an earlier Court:

The right to trial by jury and the immunity from prosecution except as the result of an indictment may liave value and importance. Even so, they are not of the very essence of a sclieme of ordered liberty. . . . Few would be so narrow or provincial as to maintain that a fair and enliglitened system of justice would be impossible without them.

Id. (quoting Palko v. Connecticut, 302 U.S. 319, 325 (1937)). To dismiss sucl generalized analysis is in itself to break from established interpretation-an irony that did not escape Justice Harlan, who in dissent reminded the Court that "due process of law," a concept that lies at the heart of the common law tradition, "requires only that criminal trials be fundamentally fair." 391 U.S. at 186-87 (Harlan, J., dissenting).

154. 407 U.S. at 501.

155. See supra note 87 and accompanying text. 
damental interests. The challenge is not so inuch to define the rights to protect, but rather to determine how to protect those rights already articulated.

The discussion thus far has suggested some theoretical and practical difficulties in addressing such questions. The next Sections consider these difficulties more directly in terms of the two leading California cases-Harris, which enforced the cross-section principle with unprecedented vigor in the early stage of venire selection, and Wheeler, which began the revolt agamst Swain by extending the primciple of cross-sectionality into the stage of voir dire. The concluding Sections summarize the complications that inhere in the present system and offer suggestions for cliange.

\section{B. People v. Harris: The Practical Problems of Enforcing Cross-Sectionality in Venire Selection}

In People v. Harris, ${ }^{156}$ a plurality of the California Supreme Court upheld a criminal defendant's challenge to a jury venire compiled by random draw from a voter registration list. The court declared that reliance on the hist had resulted in a systematic, constitutionally significant underrepresentation of blacks and Hispanics on the venire, thus violating the defendant's right to an impartial jury under the sixtl amendment and the California Constitution. ${ }^{157}$

The defendant offered the results of a survey of Long Beach Superior Court jury panels. The data indicated that between May 5 and August 19, 1979, 5.5\% of veniremembers had been black and 3.4\% Hispanic. Harris compared these figures with total population data for Los Angeles County, which establislied that in $197511.6 \%$ of the population had been black and 21.3\% Hispanic. At the time, these figures were projected to increase by 1980 to $15-17 \%$ and $33 \%$, respectively. The data did not exclude illegals, minors or others ineligible to serve as jurors. In addition, they reflected a larger geographical area than that defined by statute as the potential source for Long Beach jurors. ${ }^{158}$ In denying Harris' motion to quasli the venire, the trial court had reasoned that these statistics could not support a prima facie case because they did not allow a comparison between the venire and those eligible to vote. ${ }^{159}$

The major impact of Harris arises from its relative rigor in enforcing the second element called for in Duren-proof that a cognizable group has been unfairly represented in relation to its numbers in the cominunity. Nevertheless, even though the court showed an unprecedented

156. 36 Cal. 3d 36, 679 P.2d 433, 201 Cal. Rptr. 782, cert. denied, 105 S. Ct. 365 (1984).

157. Id. at 59, 679 P.2d at 446,201 Cal. Rptr. at 795 .

158. Id. at 46-48, 679 P.2d at 437-39, 201 Cal. Rptr. at 786-88.

159. Id. at 48, 679 P.2d at 439, 201 Cal. Rptr. at 788. 
commitinent to the principle of representativeness as espoused in Taylor and Duren, it addressed only one of the many difficulties that attend any effort to enforce the cross-section requireinent. Indeed, given the nuinber of issues it ignored, the case serves to express little more than an ambition fully to enforce the federal standard.

To enforce its requireinent that venires be randomly selected froin representative source lists, the court rehed to an unprecedented degree on the interpretation of data. To recognize the increasing authority of statistical analysis, ${ }^{160}$ however, is not to determine whicl statistics are appropriate to consider. The decision avoided discussing whether the challenger's use of county-wide figures was justified. ${ }^{161}$ Justice Kaus pointed out that the unusual statute restricting jury selection to a twentymile radius around the Long Beach courthouse inade this case a "poor trigger" for review of the standard. ${ }^{162}$ However, this very coinphication, had it been addressed, might have helped clarify the strength of the coinpeting interests. It also miglit have underscored the practical difficulty of enforcing the cross-section requirement when appropriate data are not readily available. ${ }^{163}$

Several related issues arise in considering the court's response to the twenty-mile-radius issue. First, it is questionable whether the limit itself is consistent with constitutional inandates. This restriction was presuinably designed to accommodate jurors. The appropriateness of this gesture seeins debatable, given the fundamental nature of the gnarantee tliat a jury will be chosen froin a representative cross section. By not questioning the imposition of such eccentric conditions on jury service, the court may have shighted its duty to inoritor the systemic impartiality of the selection procedure. ${ }^{164}$

160. See id. at $71 \mathrm{n} .1,679$ P.2d at 455 n.1, 201 Cal. Rptr. at 804 n.1 (Grodin, J., concurring). For arguments in support of statistical authority, see sources cited supra note 52.

161. Justice Kans rightly noted that the court might have considered whether the use of such figures was consistent with the 20-mile-radius limitation for drawing Long Beach jurors. $36 \mathrm{Cal}$. 3d at 75, 679 P.2d at 458, $201 \mathrm{Cal}$. Rptr. at 807 (Kaus, J., dissenting) (citing cases). As Justice Grodin suggested, the court might have remanded the issue for clarification, thereby deferring and perhaps avoiding the need to reverse the conviction. Id. at 71-72 \& n.1, 679 P.2d at 455-56 \& n.1, $201 \mathrm{Cal}$. Rptr. at 804-05 \& n.1 (Grodin, J., concurring). The lead opimion deftly sidestepped the question as not properly raised on appeal. Id. at 48,679 P.2d at 439,201 Cal. Rptr. at 788.

162. Id. at 75, 679 P.2d at 458, $201 \mathrm{Cal}$. Rptr. at 807 (Kaus, J., dissenting).

163. There may likewise be a lack of data reflecting the percentage of eligible jurors falling within a particular cognizable group. Cf. United States v. Newman, 549 F.2d 240 (2d Cir. 1977), in which the court rejected the use of district-wide data in a challenge to the use of peremptories, noting that division-wide data slould lave been used. Whether right or wrong, this conclusion at least reflects a disciplined application of the cross-section requirement.

164. However, this is not to suggest that the conclusion was wrong. By allowing county-wide comparative data, the court effectively precluded any possibility that such ad hoc statutes might work to "pack" juries. Insofar as Los Angeles County juries must reflect the demographic patterns of the entire county, the juror's interest in convenience is properly subordinated to the cliallenger's interest in cross-sectionality. While the result thus seems correct, there is a disturbing possibility 
To avoid considering which comparative data are appropriate is arguably to treat the cross-section requirement as less than fundamental. Such reluctance to resolve the issues that arise in enforcing a fundamental right seems consistent with the spirit of a statute that allows exclusive rehance on voter registration hists only if supplementation proves inconvemient or expensive. ${ }^{165}$ Similarly disturbing is the court's willingness to allow the substitution of general population data for more meaningful figures reflecting only those eligible for jury duty or the overall population above the age of eighteen. ${ }^{166}$ To what extent such judicial tolerance skews factual analysis remains uncertain, but the court's caution in addressing practical difficulties seeıns inappropriate: adıninistrative convernence should not warrant compromising a fundamental right. ${ }^{167}$

The court's treatment of the remaining two eleinents proposed in Duren was similarly flawed. Harris retained the two-pronged Rubio test for determining cognizability, for instance, notwithstanding the court's apparent conviction that the standard violates the cross-section principle. ${ }^{168}$ The decision likewise retained without cominentary the Duren requirement that a challenger prove that unfair representation has characterized venires over a significant period of time. ${ }^{169}$ However, in acknowledging the probative force of statistical evidence, Harris would seein to invite inquiry as to whether data in a specific case might not be adequate to support a prima facie case.

The challenger perhaps might better fulfill his initial burden by showing a single instance of significant statistical disparity. The government inight then be charged in rebuttal with showing that no discrepancy arose in other venires compiled in rehiance on the challenged procedure. The court might have based its refusal to so allocate the burdens on the availability of statistics reflecting historical venire composition-data a defendant could produce to challenge the workings of a facially neutral selection procedure. This refusal, however, also reflects an unsupported conclusion that single-case data lack the statistical significance to support

that the court reached it inadvertently as a result of the state's failure to raise the issue of countywide figures on appeal without fully appreciating its underlying logic. It is particularly disurbing that Justices Kaus and Grodin, as the sole nembers of the court willing to consider the issue, opined that the challenger's rehance on such data was indeed inappropriate. $36 \mathrm{Cal} .3 \mathrm{~d}$ at $7 \mathrm{I} \mathrm{n.1,679} \mathrm{P.2d}$ at $455 \mathrm{n.l}, 201 \mathrm{Cal}$. Rptr. at $804 \mathrm{n.l}$ (Grodin, J., concurring); $36 \mathrm{Cal} .3 \mathrm{~d}$ at 75, 679 P.2d at 458, 201 Cal. Rptr. at 807 (Kaus, J., dissentimg).

165. Cal. Civ. Proc. Code $\$ 204.7$ (West 1982 \& Supp. 1985).

166. Cf. Harris, 36 Cal. 3d at 71 n.1, 679 P.2d at 455 n.1, 201 Cal. Rptr. at 804 n.I (Grodin, J., concurring).

167. See Frontiero v. Richardson, 411 U.S. 677,690 (1973).

168. See supra note 52 and accoinpanying text.

169. The court's commitment to the Duren standard might reflect a recognition that the nature of review changes from venire selection to voir dire as attention shifts from procedural elements of the selection mechanism to the specific exercise of officially sanctioned discrction. 
a system-wide challenge. ${ }^{170}$

Harris calls into question whether even Cahfornia's activist Supreme Court has a fundamental commitment to representativeness as a condition of systemic impartiality. While the court pursued the cross-sectional ideal by rejecting an unrepresentative source hist, the decision seems oddly lackadaisical in its failure to address important related issues. It fails to explain why the government should not provide more meaningful data to validate the state's detachment, why circumscribing the commumity should escape judicial review, or why a criminal defendant's fundainental niterest should be subordinate to admimistrative convenience in the clioice of source lists.

Duncan suggested that common law principle resides solely in its enacting procedures. Despite its relative activism, the court in Harris accepted that premise and avoided abstracting principle from practice. It consequently validated questionable procedures without analysis and honored principle only by the exercise of a rhetoric that resists reliable translation into practice.

\section{Wheeler: Cross-Sectionality and Petit Juror Impartiality}

Wheeler established appropriate antmiajoritarian priorities in its atteinpt to remedy Swain's more flagrant mequities. Nevertlieless, the California Suprenie Court proposed a scheme that is both theoretically and practically problematic. The difficulties arise primarily from the court's impulse to enforce throughout the selection process tlie notion of impartiality developed in the venire-composition cases. It is this impulse which gave rise to the court's elusive dichotomy between group bias and specific bias. The immediate inspiration for this distinction was a lawreview commentary which appropriately interpreted Taylor as implying that "the rationale behmd [the] representative cross-section rule suggests tliat an impartial jury is one in which group biases have the opportunity to interact."171 The comment posited an example based on the assuniption that blacks as a group might be more inclined to acquit than whites. This mclination should not warrant the exercise of a peremptory challenge, the comment suggested, since the bias in question was not casespecific: "The representation on juries of these differences in juror attitudes is precisely what the representative cross-section standard elaborated in Taylor is designed to foster." 172 Such a predisposition, in short,

170. If single-case data might actually be significant enough to support generalizations about the systein, the present pohicy indefensibly discourages possibly unsophisticated challengers from defending their fundamental interests.

171. Comment, Limiting the Peremptory Challenge: Representation of Groups on Petit Juries, 86 YALE L.J. 1715, 1733 (1977).

172. See id. at 1733 n.77. 
presumably constitutes an element of the group common sense Taylor set out to protect and should not serve as a basis for striking a juror.

Even ignoring the logical impropriety of defining impartiality as a function of bias, it is impossible to ignore the complications that arise when this reasoning is extended into the stage of voir dire. To begin with, distinguishing a permissible group bias from an impermissible specific bias is far simpler in theory than in practice. This difficulty is coinpounded by the understandable tendency of counsel caught up in adversary proceedings to be equally antipathetic to all bias. It is safe to assume that counsel will conduct voir dire not to enforce finespun judicial distinctions but rather to eliminate all perceived prejudice. To the extent this practice conflicts with judicial policy, counsel will can take care to conceal what is happening by conducting a charade of probing voir dire before exercising as many pereinptories as will withstand discovery and challenge. This strategy will succeed under Wheeler's very broad guidelines ${ }^{173}$ so long as the pattern of peremptories is not too egregious and the voir dire appears to be directed at case-specific bias.

Furthermore, an unqualified commitınent to the notion of impartiality as a balance of prejudices inay provide a formula for hung juries, since an opposition of biases is not likely to be resolved within the confines of a jury room. ${ }^{174}$ Most importantly, the principle of balancing perspectives in the name of impartiality-questionable even on a macroscopic scalesimply will not work within a petit jury, where significant group perspectives will be excluded because of numerical limitations.

Exempting group bias froin challenge thus threatens the ideal of impartiality as "appropriate indifference,"175 which is the only sense of that term that has meaning in the final stage of selection. The coinmitinent to representativeness should carry over into voir dire only to the extent that the ideal jury will constitute a microcosin of the impartial, rather than the general, commumity. ${ }^{176}$

173. See supra notes $117-27$ and accompanying text.

174. In the succinct phrasing of one coininentator, "it is at best simplistic to assuine that every petit juror has a group bias based on immutable characteristics such as race or sex that is strong enough to affect her vote but weak enough to be swayed by deliberating with the other jurors." Comment, supra note 67, at 1782 (footnote omitted).

175. United States v. Wood, 299 U.S. 123, 146 (1936).

176. In affirming and extending its formula, Wheeler accurately sumınarized the standard argunent in favor of indiscriminate cross-sectionality: "The rationale of these decisions, often unstated, is that in our heterogeneous society jurors will inevitably belong to diverse and often overlapping groups ... ; that it is unrealistic to expect jurors to be devoid of opinions, preconceptions, or even deep-rooted biases derived from their life experiences in such groups; and hence that the only practical way to achieve an overall inpartiality is to encourage the representation of a variety of such groups on the jury so that the respective biases of their meinbers, to the extent they are antagonistic, will tend to cancel each other out." Wheeler, 22 Cal. 3d at 26667, 583 P.2d at 754-55, $148 \mathrm{Cal}$. Rptr. at 896 (enuphasis added, footnote ounitted). 
In examining this conflict, the question arises whether legitimate sixth amendment interests have been compromised by unrelated priorities carried over from the tangled history of fourteenth amendment challenges. ${ }^{177}$ The courts appear to have accepted the notion that perspectives will not merely balance but lead to consensus. They further have assuined without examination that consensus will amount to common sense, and common sense to impartiahty. These positions suggest a commitment to a procedural ideology apphicable under the sixth amendment only at an earlier stage of review, when the issue of impartiality poses itself in terms of the system's detachment in empanelling a proper range of perspectives. ${ }^{178}$

The court's impnlse in Wheeler to defend all interests equally throughout the selection process while at the same time preserving certain elements of the common law tradition of challenges led inevitably to internal theoretical contradictions. In its proscription of "specific bias," the court undermmed its own logic regarding the balancing of prejudices. Case-specific biases, after all, are fully as likely as group biases to offset each other. There is thus little theoretical basis for disallowing one and not the other.

The Wheeler court afforded counsel a power to trump chance-to adjust for an unfair balancing of prejudices by striking all agents of mamifest, case-specific bias. This grant represents an acknowledgment of the distance between representativeness and impartiahty. And yet the sanctioming of group prejudice seems a regrettable concession, since it vahdates the cynical assumption that we are in all likelihood blinded by our affiliations. The effect is to dismiss impartiality as a fiction and to exalt representativeness as an unavoidable surrogate. Such "realisin" seems at the very least to modify the expectations of the drafters of the sixth amendment. ${ }^{179}$

177. These priorities were itemized by Justice White in Duncan. See supra text accompanying note 9. Duncan sought to measure systemic impartiality in terms of the protection afforded various parties' due process and equal protection interests.

178. Wheeler continued to stress the varied priorities of fourteenth amendment review, despite the fact that at the stage of voir dire the system's detachment is no longer at issue. Notwithstanding its inerits, the case underestimated the extent to which voir dire represents a deliberate retreat from disinterested selection-one based on a recognition that discretion nust ultinately be exercised in defense of the defendant's overriding interest in impartial judgnuent.

In his discussion of challenges, Van Dyke toys with the idea of dispensing with peremptories altogether, since "if we are committed to a coinpletely representative jury, it is anounalous to allow either side to eliminate a juror thought to be unfriendly to its position." J. VAN DYKE, supra note 11 , at 168 . The argument that "[t] he use of peremeinptory challenges inevitably makes the jury more homogeneous than the population at large," id., apphies equally to challenges for cause, however, and Van Dyke's reluctance to question the latter suggests the logical weakness of equating inpartiality with representativeness in the final stage of selection.

179. Van Dyke suggests that the primary rationale for trial by jury offered by Justice White in Duncan was shared by the Framers-to avoid government oppression by interposing an impartially 
Perhaps the distinction between representativeness and impartiality can be constitutionally accommodated without a final, debilitating retreat from the notion of juror impartiality. If so, a valuable ideal of dispassionate judgment might yet be salvaged. The closing sections of this analysis attempt to provide a framework for such an accommodation.

\section{A Proposed Model for Theoretical Analysis}

The problems discussed above suggest a reluctance to enforce the standards supposedly in effect. This reluctance, in turn, may reflect confusion about the interests protected at any given stage and the extent to which those interests truly are fundamental. This Section attempts a more rigorous isolation of the particular interests that attach at each stage of review, without initial recourse to the counterintuitive formulas that have coine to be accepted as conditions of impartiality. In Duncan, the various interests itemized by Justice White were made to coalesce, and the resulting hybrid was labelled "impartiality" to accord with the language of the sixth amendment. This label has the regrettable result of obscuring a shift im the proper object of review. At the venire-selection stage, the focus of examination is on the conduct of the government as the system's author; at voir dire, the emphasis shifts to the mental state of the veniremembers as its potential agents. This adjustment reflects not only a shift in the priority of interests as selection proceeds, but also a realignment of affiliations annong the parties. In the early phases, the challenger's objective is to inaximize participation as a check on government partisanship. This goal dovetails with the potential juror's interest in serving and the government's interest im promoting citizen participation and confidence in the administration of justice. For this reason, the judiciary has granted the challenger standing to sue in defense of third-

selected body of citizens between a defendant and the state. See id. at 7-8, 47, 75. The question, however, is whether this ambition entailed equating impartiality with representativeness. In discussing challenges, Van Dyke approves the general principle of striking biased jurors. See supra note 178; see also the early holding of Chief Justice John Marshall that counsel must be allowed to question potential jurors for bias.

The relationship may be remote; the person may never have seen the party; he may declare that he feels no prejudice in the case; and yet the law cautiously incapacitates him from serving on the jury because it suspects prejudice. . . . He will listen with inore favor to that testimony which confirms, than to that which would change his opinion; it is not to be expected that he will weigh evidence or argument as fairly as a man whose judginent is not made up in the case.

J. VAN DYKE, supra note 11, at 142, 143 (quoting United States v. Burr, 25 F. Cas. 49, 50 (D. Va. 1807) (No. 14,692g)). This defense of the right of challenge was hardly atypical; as Van Dyke reports, the right was specifically mentioned in the first draft of the sixth amendment and then dropped only because the phrase "impartial jury" was held sufficient in itself. Id. at 142. The clear imphication is that the Framers conceived the sixth amendment as guaranteeing an unbiased selection of unbiased jurors. 
party interests. In the final phase, by contrast, the defendant will seek to exclude anyone whose actual or possible sympathy he suspects. Thus, his challenge may now compromise those interests with which he was previously aligned.

Cases like Soares, Crespin, and Wheeler, which aggressively enforce the cross-section requirement in voir dire, ${ }^{180}$ minimize the significance of this realignment. Unfortunately, as a result the unexamined tension among various interests may lead to constitutionally inappropriate compromises. Wheeler, for instance, concentrated so intensely on assuring the neutrahity of procedural meclianisms - a priority that should be primary only at the stage where the government assembles prospective jurors-that it stifled review for individual partiality in voir dire. A more principled assignment of constitutional interests would have compelled the court to declare the priority of one interest over the others in the event of a conflict. In Wheeler, the fundamental sixth amendment guarantee of trial by an impartial jury should liave been held to predominate over the fourteenth amendment right to random selection of jurors from a representative cross section of the cominunity. ${ }^{181}$

Wheeler represented personal prejudice as a virtually necessary condition of group identity. Its reluctance to countenance the wholesale exclusion of presumptively biased group members inarks a strategic retreat from the concept that individual predisposition to judgment is a proper concern in reviewing for impartiality. What is perliaps most unfortunate in this retreat is that it was undertaken without proposing a workable alternative. In substituting the principle of representativeness for that of juror indifference, it ignored the fact that cross-sectionality can apply only on a far broader scale than tliat of the petit jury and that it serves to protect interests only indirectly related to jury impartiality.

The California court's great error hes not in suggesting that a prospective juror's equal protection interest survives into voir dire. A juror's interest in serving is in no way dininished smiply because he becoines subject to the meclianisin of cliallenges. The mistake rather consisted in the refusal to subordinate this equal protection interest to the cliallenger's right to mipartial judgment.

Isolating these interests within different categories can help clarify the situation. Both the challenger's due process imterest in dismterested

180. See supra notes $116-39$ and accompanying text. The greater subtlety of Wheeler's analysis consists in its refusal to rely on statistical data alone as supporting a challenge.

181. The approach adopted in Wheeler may have proceeded from an unwitting disregard for the fact that the defendant's and the potential juror's interests during voir dire no longer coincide, as they necessarily do at the stage discussed in Taylor. More likely, the invocation of Taylor in this different context marks a deliberate capitulation to what was perceived as an inescapable pattern of American racial history-an adjustment of policy based on an unfortunate presumption that prejudice is and will reinain both group-specific and too prevalent to be scotched. 
venire selection and the juror's interest in serving are best located within the fifth and the fourteenth annendments, in a category remote from the challenger's interest in being judged by impartial jurors. By contrast, the challenger's interest is best protected under the sixth amendment. The state's defense of this sixth amendinent interest then can qualify as sufficiently coinpelling to warrant potentially coinpromising a juror's less fundainental interest in serving.

Suggesting that the defense of a sixth amendment interest might limit the defense of a related fifth or fourteenth ainendinent interest is considerably inore coinprehensible than proposing that separate sixth amendment interests potentially conflict in voir dire. Unfortunately, however, the Supreme Court has shown hittle inclination to distinguish the interests at stake in the various stages of jury selection. ${ }^{182}$ Moreover, while the Court seeins willing to develop a sixth ainendinent standard for review of voir dire, ${ }^{183}$ it is unlikely that it will recharacterize the challenger's constitutional interest in a neutral procedure for venire selection. To do so would reverse the present systen, which applies the fourteenth amendinent analysis of Swain to review of voir dire and the sixth amendinent analysis of Taylor to the earhier stages of the selection process. Assuming that the Court is prepared to impose sixth amendinent guidelines for all phases of juror selection, the one hope is that the focus will shift from procedural neutrality in the early stages to juror neutrality in voir dire.

\section{E. Some Practical Suggestions for Change}

The analysis of the preceding Section invites soine practical conclusions. First, it seeins unwise to posit a norm for the toleration of group bias, as proposed in Wheeler, since this phenomenon is both impossible to isolate and inconsistent with the constitutional mandate of inpartiality. More generally, any reconsideration of Swain based on a systematic ordering of constitutional interests should establish what no court in any jurisdiction has yet ventured to hold-that the peremptory challenge, despite its venerable history as a common law procedure, cannot be justified in terins of either common-law or constitutional principle. The peremptory challenge abridges the potential juror's fifth and fourteenth amendment interest in serving without any deinonstrable, inuch less coinpelling, gain in jury impartiality. The rationale for allowing pereinptories is that partiality is inore readily sensed than established and that the goal of asseinbling impartial jurors is best served by allowing exclusions that cannot be supported. Compelling evidence suggests,

182. Justice White's conflation of interests in Duncan aptly illustrates this disinclination. See supra notes 9-13 and accoinpanying text.

183. See supra note 13. 
however, that hostility is remarkably difficult to identify im a potential juror disinclined to reveal it. ${ }^{184}$ A significant danger thus exists that the exercise of peremptories will be largely arbitrary. This possibility should not be tolerated in light of a prospective juror's fundamental interest in participating im judgment.

The history of challenges under both Swain and decisions modifying it illustrates that an abuse of the peremptory challenge is far more difficult to document than irregularities at earlier stages of the selection process. As a result, a challenger ironically has a significant power of protest only when he has least at stake. What most concerns a defendant is obviously the eventual composition of his own jury. His protests, however, have a significant chance of success only when they concern the selection of the pool of veniremembers-tlie procedural stage inost distant from his true self-interest. The challenger will most likely raise these objections cynically, in the spirit of a private attorney general, imvoking abstract state and third-party interests while privately conceiving himself as exploiting a technicality. During voir dire, by contrast, when choices crucially inpinge on his most immediate interests, this power of protest is radically limited. ${ }^{185}$

Swain itself expressed theoretical concern for insuring cross-sectionahity over time. ${ }^{186}$ Moreover, those jurisdictions that have modified Swain by adopting various forms of cross-sectional analysis should recognize peremptories as coinpromising a defendant's interest in preserving the balance of perspectives on his jury. Wheeler recognized as much im developing its virtually unenforceable proscription of peremptories directed against group bias. Indeed, it is difficult to understand why Wheeler permitted any challenges, case-specific or otherwise, if it took seriously its own equation of impartiahity and cross-sectionality. ${ }^{187}$

Given the criminal defendant's interest im voir dire, the Supreme Court should regulate the process of cliallenges in a way that maximizes both the defendant's power of protest and an appellate court's power of meaningful review. Discretionary procedures, however, lack predictability, and their results consequently are not ainenable to straightforward review. ${ }^{188}$ The impulse to rely on statistics reflects the convention for

184. See Zeisel \& Diamond, The Effect of Peremptory Challenges on Jury and Verdict: An Experiment in a Federal District Court, 30 STAN. L. REv. 491 (1978).

185. Wheeler admittedly moved in the direction of adjusting this imbalance by enhancing the possibility of successfully challenging voir dire examination, but it left intact the oddly inverted shape of the standard.

186. See supra note 84 and accompanying text.

187. See supra note 179 and accompanying text.

188. Indeed, one major conceptual danger in such state-court formulations as appear in Soares and Crespin arises from their call for an effect-oriented cross-sectional analysis in reviewing a discretionary proceeding. The Court in Commonwealth v. Soares, for instance, rehed purely on statistical data as a basis for its decision, 377 Mass. 461, 490, 387 N.E.2d 499, 517, cert. denied, 444 
reviewing other, prior selection procedures, where the goal is to insure randomness and significant statistical disparities can provide more certain proof of a violation. However, where a procedure is designed precisely to inodify chance, review should proceed along different lines. Under such circumstances, a statistical disparity becomes significant only in the rare event that it diverges from the broad range that one might expect. Given the meager likelihood of this outcoine, analysis of results does not provide adequate procedural protection. ${ }^{189}$

The proper focus in reviewing discretionary exclusions is their reasonability in terms of the record. Under this principle, the problem with peremptories is precisely that they are peremptory-that they can be exercised without any offermg of reasons and so produce virtually no record beyond inere statistics. ${ }^{190}$ Because it is resistant to effect-oriented analysis, the system lends itself to mampulation by counsel inclimed impermissibly to strike jurors on the basis of group affiliation alone.

In light of these risks, one might wonder why the peremptory challenge continues to be so widely accepted. The answer lies partially in the mertia of a system that attaches great persuasive force to a common law procedural heritage. ${ }^{191}$ More importantly, the device has the cardinal

U.S. 881 (1979), and at no point expressed the reservations clearly felt by the court in Wheeler concerning such exclusive reliance. In its preoccupation with "the absolute number of challenges in one case," see supra notes 136-39, Crespin similarly focused on the effects of discretionary processes, rather than the manner of their exercise. Unlike Wheeler, $22 \mathrm{Cal} .3 \mathrm{~d}$ at 279-80, 583 P.2d at 763-64, 148 Cal. Rptr. at 904-05, see supra note 121 and accompanying text, both cases overstressed the probative value of statistics as signalling a violation.

189. Swain attempted to remedy this problem by insisting on proof of historical disproportion so overwhelming that an inference of improper inotive was inescapable. The unfortunate effect was to compromise the challenger's interest in due process. See supra notes 84-86 and aceompanying text.

190. Despite the half-hearted mcasures in Wheeler and related state cases to provide guidelines for the exercise of peremptories, thereby effectively narrowing the distance between peremptories and challenges for cause, a defendant's burden in compiling an adequate record to support an appeal remains inordinate. The peremptory challenge should therefore be recognized as not only overly susceptible of deliberate abuse, but also constitutionally suspect even if exercised in good faith. For example, jurisdictions employing a struck-juror system have adopted a formalized operation whereby opposing counsel alternately winnow down a panel by largely arbitrary peremptory challenges until it reaches an appropriate size. This ritual needlessly narrows the range of permissible perspectives that has been so assiduously sought in earlier phases. See J. VAN DYKE, supra note 11, at 154 .

191. See supra notes $147-53$ and accompanying text. It is worth recalling, however, that even the common law pedigree of peremptory challenges is not unblemished. The English, for instance, have since 1305 limited pereinptories to the defense, see People v. Frazier, 469 N.E.2d 594, 600 (Iil. App. 1984). They have since abolished peremptories in civil trials and largely restrieted their use in criminal proseeutions, see J. VAN DYKE, supra note 11, at 169. Massachussets nearly dispensed with the practice in 1974. See id.

Van Dyke describes the abolition of pereinptories as "an idea whose time inay be coming" and suggests that at the very lcast a radieal curtailment seems appropriate. Id. His approval arises, however, from a concern to preserve "the jury's demographic coinposition," and he concludes with the highly debatable proposition that "[i]f our jury panels reflect inore closely the population at large, then the need for extensive questioning and prolonged challenge will be greatly reduced." Id. 
virtue of simplicity, sparing the courts time and resources that would otllerwise be spent inquiring into a mental state whose perceptibility is itself debatable. Finally, the practice enables counsel to strike jurors wlio were alienated by the very examination designed to uncover their hostility.

Of these justifications, the first two are far from compelling. The institutional pedigree of a practice should not refute a principled objection based on the compromise of constitutional rights. ${ }^{192}$ Given the strength of the constitutional interests at stake, courts should recognize a continuing hazard im exalting the procedural sunphicity peremptories offer. The challenge they face is to strike a constitutionally defensible compromise between the extremes of promiscuously exercised peremptory challenges and potentially interminable voir dire.

In determining where this balance should be struck, the paramount concern must be to assure meaningful review. In addition, it is important to revise the current majority policy of according extraordinary deference to trial-court determinations of the appropriateness of both peremptory challenges and exclusions for cause. This unusual respect for the discretion of the trial court is symptomatic of the problem with peremptories. Because the trial judge is in a umque position to appreciate the countless intangible elements that form the basis of an exclusion, the reviewing tribunal lias no clioice but to defer. Nevertleeless, this factor is greatly inagnified in the exercise of peremptories and poses the threat of effectively thwarting review.

Ratlier than abandon meaningful review of decisions inade in the discretionary phase of juror selection, the judiciary sliould maximize the extent to which exclusions must turn on reviewable elements. The first step towards achieving that end is to locate greater power in the court, rather than to continue granting counsel carte blanche to exclude within a certain statistical range. ${ }^{193}$ In addition, this step will accommodate

Representativeness alone will neither insure nor necessarily enhance juror impartiality. The justification for dispensing with pereinptories is rather that they can be exercised for reasons renote froin the issue of impartiality and hence potentially compromise a series of related constitutional interests.

192. For a discussion of which rights are compromised under the fourteenth amendinent alone, see Coinment, A Case Study of the Peremptory Challenge: A Subtle Strike at Equal Protection and Due Process, 18 ST. Louis U.L.J. 662 (1974); Comment, The Prosecutor's Exercise of the Peremptory Challenge to Exclude Nonwhite Jurors: A Valued Common Law Privilege in Conflict with the Equal Protection Clause, 46 U. CiN. L. REv. 554 (1977).

193. To limit the likelihood that such a change would promote interminable voir dire examination, the standard for supporting a challenge for cause should be broadened. Swain described the challenge for cause as founded on a "narrowly specified, provable and legally cognizable basis of partiality," whereas the peremptory challenge may be exercised "without inquiry and without being subject to the court's control." Swain v. Alabaina,380 U.S. 202, 220 (1965). The narrow bases that will support a challenge include having served on the grand jury that issued the indictment, Cal. Penal Code $\S 1074$ (West 1970 \& Supp. 1983); N.Y. Crim. Proc. Law 
those borderline cases now dealt with peremptorily and allow for a conventional standard of appellate review. At a stage of selection that imvolves the exercise of discretion both by counsel and by the trial court, judicial review is the best guarantee of due process.

Locatimg greater power in both trial and appellate courts could inspire several objections. First, to do so precludes the one use of peremptories that is constitutionally justifiable-striking jurors who have been unavoidably ahenated by inquiry into their attitudes. This problem might be resolved, however, without relying on pereinptories. For example, the record of the examination that resulted in alienation might itself be held to support a challenge for cause. Recategorizing this variety of challenge has the significant advantage of producing a record on which to determine whether unscrupulous counsel has dehberately set out to alienate a juror because of his group affiliation or general demeanor. Counsel would thus run an imposing risk, only mimmally present under the current systein, that the court would recognize dehiberate efforts to create such a cause and reject the challenge.

A more theoretical objection might be based on the principle of governmental nonoppression, which Justice White identified in Duncan as underlying the right to trial by jury. ${ }^{194}$ Increasmg judicial control over jury coinposition will empower the government to manipulate the nature of the body of citizens that will stand between the state and a defendant. Meaningful appellate review, however, will greatly limit such potential abuse.

Given the current theoretical and practical problems in the jury selection system, there are three options. We can either locate control in a judiciary desigued to pohce its decisions by an appellate process that focuses above all on constitutional priorites; retam a system that vests control largely in the hands of partisan counsel, who can wield their power secure in the knowledge that their actions are beyond meaningful appeal; or dispense with control altogether, relying purely on chance

$\S 270.20(1)$ (e) (McKinney 1982), kinship with the defendant, CAL. PeNAL CoDE $\$ 1074$ (West 1970 \& Supp. 1983); N.Y. CRIM. Proc. LAW $\S 270.20$ (1)(c) (McKinney 1982), and having served on a jury before which the same defendant was tried on a related charge, id. The California standard breaks from such purely objective measures by considering a juror's "conscientious opinions" only when an offense is punishable by death and the juror might be precluded thereby from finding the defendant guilty. CaL. Penal Code $\S 1074$ (West 1970 \& Supp. 1983).

Such a hist might be fruitfully expanded simply by detailing some broad areas of appropriate subjective inquiry and then providing that a challenge should be upheld whenever the record supports a reasonable inference of bias in the prospective juror. The effect would be to inonitor counsel's inehinations to strike jurors by subjecting them to trial court, and potentially appellate, scrutiny. Maximizing the elements of reviewable court control in this way would guard the defendant's interest in impartial judgment, the potential juror's equal protection interest in serving, and society's general interest in community participation.

194. See supra note 9 and accompanying text. 
draw from a representative source list to select juries. For reasons discussed in detail above, to adopt this last option would be to embrace cross-sectionality to an extent imconsistent with the requirement of impartiality. The issue tlius becomes not whether to manipulate the body of jurors by a discretionary process of selection, but rather how to limit that manipulation without infringing on constitutionally protected interests. A judiciary characterized by internal procedural checks is umquely designed to limit the control it itself exerts.

The concept of impartiality enforced in jury selection currently shifts as selection proceeds. In the early stages, the standard of impartiahty turns on the government's indifference in assembling jurors, and the courts measure comphance by the demographic representativeness of panels over time. In the final stage of petit jury selection, by contrast, inquiry turns on a juror's imitial indifference as to the outcome of trial. At present, only the Second Circuit has sought to define a challenger's interest in detached jurors in terms of the sixth aniendment. Various state supreme courts have developed alternative standards for the exercise of peremptories based on state constitutions. No court has yet openly acknowledged, however, that systemic impartiality in selection is logically distinct from individual impartiality in decision, and that the two involve different constitutional interests.

The courts cannot develop a consistent sixth aniendment standard for voir dire so long as they minimize this distinction. Impartiality has a dual aspect. To minimize this fact by extending cross-sectional priorities into the stage of voir dire is to commit a significant category mistake, the effect of which is to exalt systermic impartiality at the likely expense of the defendant's paramount interest in fair trial. In the stages of jury wheel and veuire selection, the prospective juror's interest in serving is rightly protected by insisting on impartially selected panels, which must be representative to the extent permitted by random draw. In the final stage, however, the defendant's interest in impartial judgment requires that attention focus on identifying and striking those jurors whose riglit to serve is qualified by deinonstrable prejudice.

Nevertheless, the prospective juror's fundamental imterest im serving survives into voir dire, and notlimg warrants its comproimise by allowing arbitrary challenges by counsel for either side. Moreover, the defendant's imterest in diversity among his jurors carries over from earher selection stages, and he should likewise be spared any arbitrary striking of veniremembers. The peremptory challenge violates both tlie juror's and the defendant's interests, then, without demonstrably protecting any other fundainental interest.

In articulatimg a sixth aniendment standard for voir dire, the courts should avoid any further suggestions that cross-sectionality is an exhaus- 
tive surrogate for impartiahty. By the same token, they should avoid exaltimg the concept of individual juror impartiality to a point where counsel can compromise both the cross-section principle and a juror's fundamental interest in serving merely on an unreviewable suspicion of bias. The peremptory challenge should be abandoned as a dangerous and unnecessary anachroinsm, and attention should focus on developing a broad and reviewable standard for exercising challenges for cause. The retreat from fourteenth amendment review of jury challenges provides a perfect occasion to effect such changes.

James H. Druff*

* B.A. 1971, College of William and Mary; M.A. 1975, Ph.D. 1979, University of California, Berkeley; third-year student, Boalt Hall School of Law, University of California, Berkeley. 